University of Louisville

ThinkIR: The University of Louisville's Institutional Repository

Electronic Theses and Dissertations

8-2011

\title{
Turning the key to success : an examination of the mathematics attitudes of African American elementary students.
}

Dericka Denise Canada

University of Louisville

Follow this and additional works at: https://ir.library.louisville.edu/etd

\section{Recommended Citation}

Canada, Dericka Denise, "Turning the key to success : an examination of the mathematics attitudes of African American elementary students." (2011). Electronic Theses and Dissertations. Paper 202.

https://doi.org/10.18297/etd/202

This Master's Thesis is brought to you for free and open access by ThinkIR: The University of Louisville's Institutional Repository. It has been accepted for inclusion in Electronic Theses and Dissertations by an authorized administrator of ThinkIR: The University of Louisville's Institutional Repository. This title appears here courtesy of the author, who has retained all other copyrights. For more information, please contact thinkir@louisville.edu. 
TURNING THE KEY TO SUCCESS:

AN EXAMINATION OF THE MATHEMATICS ATTITUDES OF AFRICAN

AMERICAN ELEMENTARY STUDENTS

\author{
By \\ Dericka Denise Canada \\ M.Ed., College of Education, 2011
}

\begin{abstract}
A Thesis
Submitted to the Faculty of the

College of Education and Human Development of the University of Louisville in Partial Fulfillment of the Requirements

for the Degree of
\end{abstract}

Master of Education

Department of Educational and Counseling Psychology

University of Louisville

Louisville, KY

August 2011 

TURNING THE KEY TO SUCCESS: AN EXAMINATION OF THE MATHEMATICS ATTITUDES OF AFRICAN AMERICAN ELEMENTARY STUDENTS

By

Dericka Denise Canada

M.Ed., College of Education, 2011

A Thesis Approved on

August 1, 2011

by the following Thesis Committee:

Thesis Director (Jill Adelson)

Linda Shapiro

Kevin Chapman

Jesse Owen 


\section{DEDICATION}

This thesis is dedicated to my parents

Mr. Derrick D. Canada

and

\section{Mrs. Marcina M. Canada}

who have given me invaluable educational opportunities. 


\section{ACKNOWLEDGMENTS}

I would like to thank my advising professor, Dr. Jill L. Adelson, for her guidance, patience, and commitment over the past two years. I would also like to thank the other committee members, Dr. Linda Shapiro, Dr. Kevin Chapman, and Dr. Jesse Owen, for their comments and encouragement during this process. I give the utmost honor to God, for without His favor, grace and mercy this journey would not be possible. Also, I give much gratitude to my parents: Derrick and Marcina Canada, my sister: Jackie Canada, my friends, sorority sisters of Alpha Kappa Alpha Sorority, Incorporated, and extended family for being such great supportive systems through all of my educational aspirations. 


\section{ABSTRACT \\ TURNING THE KEY TO SUCCESS: \\ AN EXAMINATION OF THE MATHMATICS ATTITUDES OF AFRICAN AMERICAN ELEMENTARY STUDENTS \\ Dericka D. Canada}

August 1, 2011

African American students continue to underperform and are underrepresented in areas, including mathematics (Heubert \& Hauser, 1999; Jencks \& Phillips, 1998; National Postsecondary Education Cooperative, Gandara, Bial, \& Educational Resources Information Center, 2001). Students' aspirations and beliefs about the education they are receiving frequently do not match with the perceptions of their teachers, especially for African American students (Garibaldi, 1992). Teachers of these students often perceive these students' academic ability, attitudes, and motivation negatively even though African American students may experience them positively. Two competing theories regarding how others' view of a student's abilities influences that student's academic attitudes are stereotype threat and resiliency theory. The purpose of this study was to explore these questions and research topics. Results of the current study support resiliency theory, with African American students reporting significantly greater enjoyment of mathematics than White students and reporting self-perceptions in mathematics at about the same rate as White students regardless of teachers underrating them and overrating their White counterparts on both measures. 
TABLE OF CONTENTS

PAGE

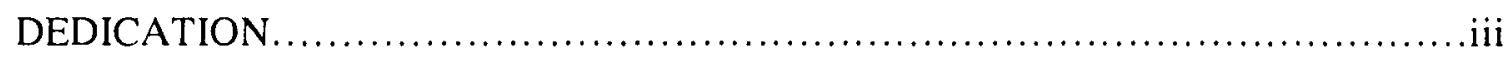

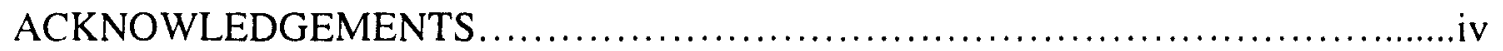

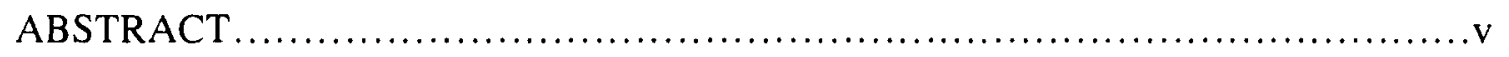

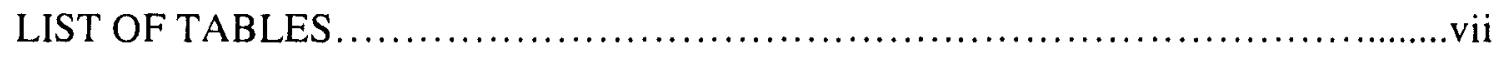

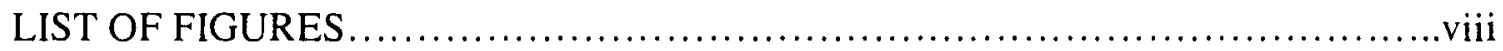

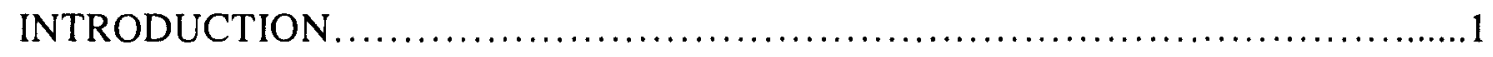

REVIEW OF RESEARCH LITERATURE $\ldots \ldots \ldots \ldots \ldots \ldots \ldots \ldots \ldots \ldots \ldots \ldots \ldots \ldots$

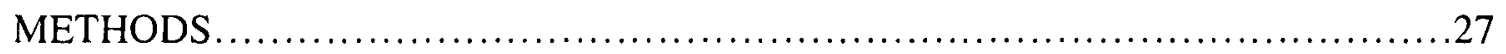

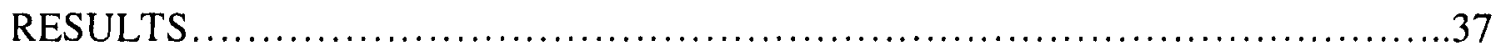

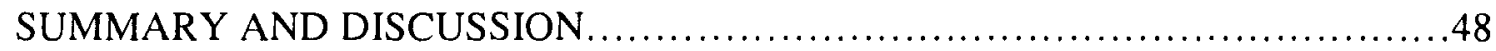

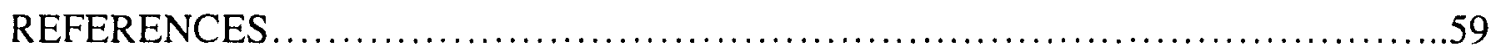

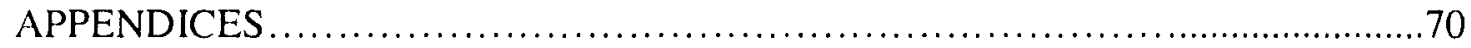

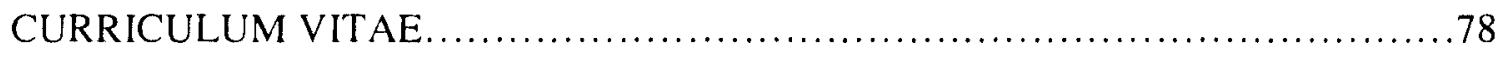




\section{LIST OF TABLES}

$\begin{array}{ll}\text { TABLE } & \text { PAGE }\end{array}$

1. Sample Population by Grade Level and Ethnicity.............................28

2. Descriptive Statistics by Variable........................................40

3. Summary of ANOVA for Students' Mathematics Enjoyment and Self

Perceptions........................................................... 41

4. Summary of ANOVA for Teacher Ratings of Student Mathematics Self-Perceptions

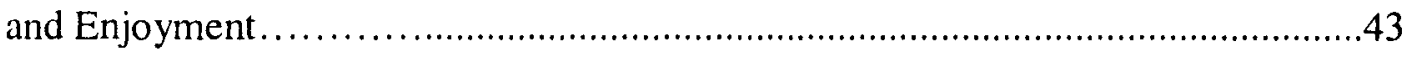

5. Correlations of Student-to-Teacher Variables for African American Students.......45

6. Correlations of Student-to-Teacher Variables for White Students................45

7. Summary of ANOVA for Mathematics Self-Perceptions and Enjoyment Difference

Scores.............................................................46 


\section{LIST OF FIGURES}

FIGURE + PAGE

1. Conceptual Model of Psychosocial Process Underlying Stereotype Threat...........16

2. Comparison of African American and White Students on Mathematics Enjoyment

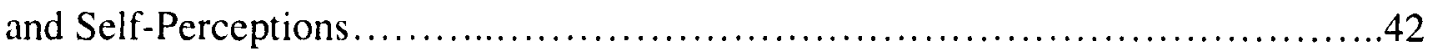

3. Comparison of African American and White Students on Teacher Ratings of Mathematics Enjoyment and Self-

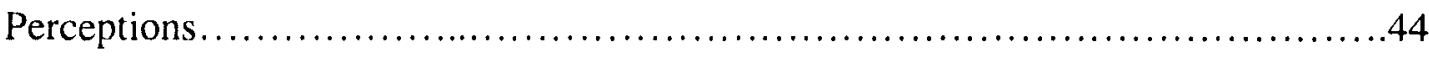

4. Comparison of African American and White Students on Mathematics Enjoyment and Self-Perceptions Difference

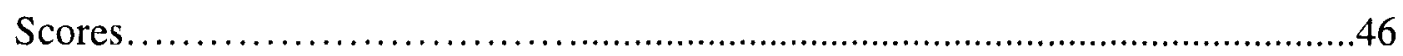




\section{CHAPTER ONE \\ INTRODUCTION}

\section{Introduction to the Topic}

Within American society there is a popular quote which holds that "education is the key to success." However, having the key to education is not enough. An individual must have the motivation and positive attitudes to use the key to unlock the door in order to experience true success. For African American students in particular, this motivation may be affected by what being an African American student in our society entails and may be centered around concepts such as attitudes, stereotypes, and expectations.

African American students continue to underperform academically and are stereotypically perceived to hold negative educational attitudes in areas such as mathematics. The concept of attitudes within the educational context refers to an individual's confidence, motivation, self-concept, and/or enjoyment of mathematics or other academic areas. There are many factors that may potentially affect the mathematics and educational attitudes of young students. Frequently discussed factors include individual characteristics (e.g. personality, own general motivational factors, sense of agency), environmental factors (e.g. aspects of community, availability of resources, societal factors), familial factors (e.g. parenting styles, parental support, role models), and educational factors (e.g. aspects of school location, school resources, teacher characteristics). These factors can also play a perpetuating role on each other. They can 
positively or negatively affect students' educational attitudes by either benefiting or disadvantaging the student's motivation to perform well. For example, a student may live in an environment where there are limited academic resources (e.g. low number of libraries, libraries with limited literature choices, little opportunity for tutoring services, limited successful academic role models.) and where educational success may not be expressed as an important facet within the community. This individual has the ability to be either positively or negatively affected by the factor of the environmental condition. The student may internalize certain characteristics (e.g. thoughts, internal beliefs, external/societal beliefs) associated with his or her environment, and these internalized characteristics may lead to an increase in negative thoughts with regards to his or her intellectual ability that, in the end, may disadvantage the student academically. On the other hand, the same student in the same environmental situation may develop a deeper understanding of his or her situation and may become motivated to excel beyond that which is seen around him or her, allowing the factor to benefit the student's motivational attitudes.

Because there are so many potential factors, particularly with varying cultural groups, it becomes difficult to examine the effects of each and every factor bearing on students. However, understanding that factors do exist and conceptualizing the effects of some of the more common factors may present itself beneficial in examining the mathematics attitudes of African American students.

\section{Statement of the Problem}

The underperformance and underrepresentation of African American students in academic areas such as mathematics continues to prevail. This continues to trouble 
educational researchers nationally. African American students have been found to perform lower academically than Whites in various subjects (Heubert \& Hauser, 1999; Jencks \& Phillips, 1998; National Center for Education Statistics [NCES], 2001). Some research contends that these students may suffer diminished performance outcomes due to harmful thoughts that may be associated with the fear of conforming to negative beliefs held about their particular cultural group (Spencer et al., 1999; Steele \& Aronson, 1995).

Students' aspirations and beliefs about the education they are receiving frequently do not match with the perceptions of their teachers. Also, parents of these students often have differing beliefs about their children's academic abilities and goals in comparison to their student's teacher (Garibaldi, 1992). The race or ethnicity of a particular student may lead a teacher to apply generalized expectations, making it difficult for them to develop expectations that are specific to individual students (Ferguson, 2003). Teachers of these students often perceive these students' academic ability, attitudes, and motivation negatively even though African American students may experience this positively. Unfortunately, negative teacher perceptions and expectations are often inflexible leading to experiences such as self-fulfilling prophecies. Teachers who hold negative perceptions of African American students could potentially negatively affect and turn away students who have high abilities, positive self-perceptions, and high expectations (Ferguson, 2003; Garibaldi, 1992). Adversely, some students express positive attitudes toward learning regardless of negative expectations or conditions that may exist (Lewis \& Kim, 2008). The aforementioned phenomena leave educational researchers to wonder what it is that seems to be causing such academic and ability gaps. Where do differences exist, if any, in 
the process of academic achievement? Because educational attitudes are considered to be a part of the academic achievement process, what do these attitudes look like among various cultural groups that may lead to their academic underperformance?

\section{Brief Review of Relevant Literature}

Most literature supports the notion that mathematics and educational attitudes can have a substantial effect on academic achievement (Dumais, 2009; Singer, Beasley, \& Bauer, 1996; Whitin, 2007). A number of studies have utilized national data to better assess the effects of attitudes on achievement (Dumais, 2009; Heubert \& Hauser, 1999; Jencks \& Phillips, 1998; NCES, 2001; NCES, 2009).

Not only does research examine the effects of academic attitudes, but it also aims to better understand how the concept of "mathematical attitudes" specifically has developed. Two relevant mathematics attitude constructs are a) students' self-perceptions of their mathematics ability, and b) their enjoyment of mathematics. Students' selfperceptions of their mathematics ability include both their self-concept (i.e., thoughts and feelings towards mathematics), and their self-efficacy (i.e., ability to master and perform in mathematics; Adelson \& McCoach, in press; Pastorelli et al., 2001; West, Fish, \& Stevens, 1980). Mathematics enjoyment reflects students' interest in the subject and is found to have an effect on student's persistence in the area (Adelson \& McCoach, in press; Tapia, 1996; Thorndike-Christ, 1991). Equally important to understanding the conceptual framework of educational attitudes is the understanding of what factors potentially affect these attitudes. Even more important than this is the understanding of differences that may exist between the effects of certain factors on various cultural groups. With regards to African American students specifically, most research supports 
the notion that most common influential factors of educational attitudes include environmental factors (including societal stressors such as racism and stereotypes), familial factors (particularly parents), and educational factors (e.g. school and teacher characteristics; Griffin \& Allen, 2006; Gutman \& McLoyd, 2000; Jencks \& Phillips, 1998; Lalley \& Miller, 2006; Lee, Winfield, \& Wilson, 1991; Lewis, 1995; Love, 2002; Midgley, Feldlaufer, \& Eccles, 1989; Nettles, Mucherah \& Jones, 2000; Wilson-Jones \& Caston, 2004).

Research on the manifestation of mathematics and educational attitudes among African American students provides two general concepts of how these attitudes develop and are displayed in academic settings. Some studies have found that negative societal views of African Americans with regards to academic ability leads to lower self-efficacy of these students in their ability to perform well in certain academic situations (Spencer et al., 1999; Steele \& Aronson, 1995; Inzlicht \& Ben Zeev, 2000). On the other hand, other studies have found the opposite to be true in African American students. Those studies suggest that regardless of what factors that may bear upon these students (both negative and positive), they are able to turn negative factors into motivational factors that encourage them to succeed in academic settings (Dass-Brailsford, 2005; Lewis \& Kim, 2008; Tyson, 2002; Watson \& Stead, 1997; Wilson \& Corbett, 2001)

\section{How this Study Contributes to Educational Psychology Research}

This study provides a deeper understanding of what attitudes towards mathematics look like for students at the upper elementary level. It adds to the existing literature by providing more up-to-date research on the topic. It has been our society's goal to raise achievement levels of our school children. Some research purports that 
academic achievement can be greatly affected by educational attitudes; therefore, better comprehension of these attitudes is necessary in order to improve academic learning experiences for students (Dumais, 2009; Singer et al., 1996; Whitin, 2007).

Because of the dearth of literature that focuses on mathematics attitudes specifically with African American elementary school students, this study will open doors for this topic to be explored even further. Research suggests that how much students enjoy mathematics and what they believe about their ability in mathematics can affect their performance in mathematics (Singer et al., 1996; Bloom, 2008; Whitin, 2007). This study will not only contribute to literature on mathematics attitudes among elementary students, but it will also provide information on if and/or how African American students and White students differ on mathematics attitudes. Existing literature on this comparison is scarce. This will not only benefit the general educational and mathematics attitudes literature but will also provide better insight to educators and policy makers across the United States who have made it their agenda to close the educational gaps between various cultural groups.

Lastly, this study will provide insight into how mathematics attitudes manifest among African American students in particularly. Research on this relationship seems to be split between two main theories (stereotype or resiliency; Dass-Brailsford, 2005; Inzlicht \& Ben Zeev, 2000; Lewis \& Kim, 2008; Spencer et al., 1999; Steele \& Aronson, 1995; Tyson, 2002; Watson \& Stead, 1997; Wilson \& Corbett, 2001). This study aims to further support a particular theory: stereotype or resiliency which will serve as the basis for understanding how African American students' attitudes are affected by their environments. 


\section{Definition of Terms}

Educational Attitudes within this study's context refers to an individual's confidence, motivation, self-concept, and/or enjoyment of academic areas.

Mathematics Self-Perceptions refer to “a person's perceptions of self as a mathematical learner, including beliefs about his or her ability to learn and perform well in mathematics" (Adelson \& McCoach, in press, p. 4).

Mathematics Enjoyment refers to an individual's positive or negative experience of mathematics and how he or she generally likes or dislikes tasks and activities related to mathematics (Adelson \& McCoach, in press).

Educational Resiliency is defined as "the process and results that are a part of the life story of an individual who has been academically successful, despite obstacles that prevent the majority of others with the same background from succeeding" (Morales \& Trotman, 2004, p.8).

Stereotype Threat is characterized by a social-psychological threat that occurs when one is at risk of being negatively judged or treated in a stereotyped manner causing that individual to anticipate the possibility of fulfilling a negative stereotype (Steele, 1998). 


\section{CHAPTER TWO \\ REVIEW OF RESEARCH LITERATURE}

Due to the exploratory nature of a survey-based study, this study focuses not only on ethnic differences in mathematics but also on the concept of mathematics attitudes as it relates to teacher perceptions in general. It seeks to determine the characteristics of mathematics attitudes, perceptions, and interests of young students.

This chapter begins with a review of the literature on general mathematics attitudes and its effects on mathematics achievement. The research reviewed focuses on attitude development, peer influences, student academic and ability perceptions, and other possible mediating factors. The second section of this chapter explores the literature on two models associated with the educational attitudes of African American students. These models include Stereotype Threat Theory and Academic Resiliency Theory. The next section reviews literature on outside factors that may affect educational attitudes and academic performance of students in general. The research reviewed explores the effects of educational environmental factors, parental factors, and teacher characteristics. Lastly, this review concludes by highlighting the exigencies for exploring the research topic. In this section, literature supports why further research in this area is needed, justifying the premises of the current study. 


\section{Literature Review of Mathematical Attitudes and Mathematical Achievement}

In 2003 an estimated $9.9 \%$ of individuals aged 16-24 were not enrolled in high school and had not obtained a high school diploma (Laird, Lew, DeBell, \& Chapman, 2006). One reason for academic underachievement among children and adolescents may be related to negative school and education related attitudes that students may possess (Brier, 1995). Disengagement from the academic environment begins prior to high school, making the research on reasons for such disengagement at an early age that much more imperative (Ogbu, 2003).

Some research suggests that there are nine main constructs that affect a student's mathematics learning: achievement motivation, career expectations, influence of parents and teachers, parental education and occupation, enjoyment of mathematics, self-esteem within mathematics, mathematics stereotypes, mathematics relevance, teacher expectations, and locus of control (Singer et al., 1996). According to Whitlin (2007), what students believe about mathematics influences their ability and willingness to excel. Assessing students' attitudes and beliefs toward education can provide essential information regarding ways in which to help students succeed academically.

Development of attitudes towards mathematics may occur at a fairly early age. Bloom (2008) states that children's attitudes about mathematics may be fixed by the age of nine. Although Bloom found that $90 \%$ of children between the ages of six and eight said they like or love math, by the time children reached the ages of nine and 12 , fewer than $70 \%$ reported liking or loving math.

Though this type of research at the elementary age may be limited, researchers often look to other age groups to make assumptions about mathematics attitudes. One 
study used data from the National Education Longitudinal Study of 1988 (NELS:88) and the Educational Longitudinal Study of 2002 (ELS:2002) to compare the academic attitudes of high school students from Generation X (adolescents in the 1990s) and the Millennial Generation (adolescents in the early 2000s). The results of this study revealed that for both age groups, the more important their peers considered academic values, the greater the respondents' mathematics achievement test scores (Dumais, 2009). Likewise, the effects of outside influences, such as peer support, seems to present itself as a consistent theme among African American students even outside of the mathematics subject to broader educational attitudes in general. One study found that African American high school students emphasized the importance of friends by relying on their peers for support and encouragement throughout the process of preparing for college (Griffin \& Allen, 2006). This reflects the effects of one's own view of mathematics as well as his or her peers' views and support on how that individual performs in the subject and makes other educational decisions such as preparing for college.

As previously noted, research suggests that how students perceive themselves academically may affect their scholastic performance (Dumais, 2009; Whitlin, 2007). This also holds true specifically with mathematics self-perceptions and mathematics performance. Skaalvik and Skaalvik (2006) defined self-perception as the way in which an individual assigns various beliefs and attributes to him or herself and examined the association between mathematics self-perception and academic achievement. The results for the eleventh graders in that study revealed that stability of grades over time was almost fully mediated through students' mathematics self-perceptions. This showed that 
mathematics self-perception predicted achievement over time, reflecting the strong effect that these self-perceptions can have on students' success.

Although research has consistently demonstrated the relationship between academic achievement and self-perceptions, research findings are inconsistent regarding the specific direction of causation between these constructs, including in mathematics (Marsh, Byrne, \& Shavelson, 1988; Marsh \& Yeaung, 1997; Shavelson \& Bolus, 1982; Skaalvik \& Hagvet, 1990; Skaalvik \& Skaalvik, 2006). For example, some researchers agree with what is defined as the skill development model, which holds that achievement affects self-perceptions (Scheirer \& Kraut, 1979). In contrast, other researchers side with the self-enhancement model, which states that self-perceptions affect achievement (Jones, 1973; Lecky, 1945). Additionally, a handful of researchers believe in what is called the reciprocal effects model, which holds that achievement and self-perceptions affect each other in a reciprocal way (Marsh, 1984; Wigfield, Eccles, \& Pintrich, 1996).

In addition to the relationship between mathematics self-perceptions and achievement, Skaalvik and Skaalvik (2006) also examined how goal orientation (both task orientation, which is focused on attention to specific tasks, and performance orientation, which is focused on desire to be judged able), interest (which they associated with intrinsic motivation, or motivation that is free from external rewards), and selfesteem (which is the general self-acceptance and valuing of oneself) affects those constructs. They found that the mediating role of students' mathematics self-perceptions increases after the transfer to a new school or new context (i.e. from middle to high school). The results of this study indicated that for both middle and high school samples the impact of self-perceptions on subsequent achievement was not mediated through goal 
orientation or interests, therefore, standing alone in its effect on achievement. Though the current study did not examine direct relationships between students' mathematics enjoyment and self-perceptions with mathematics achievement, it is important to understand the effects of enjoyment and self-perceptions on students' academic success in order to fully embrace why research on this particular topic is imperative.

\section{Theories, Models, and Relevant Ideas}

\section{Stereotype Threat Theory}

The academic underperformance of African American students in mathematics has produced much concern within the educational research world. Each year results from examination of statewide and national tests results in the same disturbing patterns with regards to underachievement. For example, compared to White students, AfricanAmerican students produce lower grades and have higher dropout rates at almost every level of education (Good, Aronson, \& Inzlicht, 2003). Specifically, African Americans have been shown to obtain lower scores on standardized tests on reading, mathematics, and science (Jencks \& Phillips, 1998). African American students score lower than White students from pre-kindergarten through college (Heubert \& Hauser, 1999; Jencks \& Phillips, 1998; NCES, 2001, 2009). In addition to this, substantial differences in AfricanAmerican-White performance remain even when accounting for demographic background variables. For example, results revealed a 20-point difference between African American and White eighth graders on the Third International Mathematics Science and Math Study [TIMSS] after controlling for SES and other background variables (Schmidt, 2003). In 1999, on average, a 3-4 point difference existed between African American and White test takers on the American College Test Assessment 
[ACT]-Mathematics section, and a 100-150 point difference on the SAT, at all income levels (including annual income levels greater than $\$ 100,000$; Nettles et al., 2000). This suggests that there is some intervening variable, even outside of simply economic background, that may be the leading factor in the existence of these deficiencies among African American students.

Some researchers propose that at the heart of this mediating factor may rest the existence of stereotype threat. In a study examining ethnicity and the performance of African American students on standardized achievement tests, high stereotype threat was linked to a decrease in the performance of high-achieving African American students (Steele \& Aronson, 1995). African American students performed more poorly than White students when the test was presented to measure specific area achievement, while they did as well when the measure of ability was not made salient before taking the test. In addition, this heightened stereotype threat was linked to an increase in thinking about the specific cultural group stereotype and increased in self-doubts associated with it for highachieving students. African American students expecting to take a test of intellectual ability experienced concerns of ability, provided excuses about their performance, and were more reluctant to allow their ethnicity to be linked to their performance, suggesting that this may be due to stereotype threat (Steele \& Aronson, 1995).

Recent trends continue to show African Americans scoring lower than White students on standardized tests, suggesting that this phenomenon is pervasive (NCES, 2001, 2009). In 2007, the gap between White and African American students in grades 4 and 8 still prevailed. Though this 2007 gap was narrower than in previous assessments White students still scored an average of 26 points higher than African American students 
in each subject, including mathematics. The 23-point achievement gap between age 9 White and African American public school students in 2004 was narrower than the gap that existed in first assessment in 1978; however, it was not significantly different than the previous assessment in 1990. The same was true for the 26-point gap at age 13 (NCES, 2009).

Much of the psychological and educational research centered on understanding these patterns suggests that sociological factors, such as teacher and societal expectations, may be the cause (Eccles, Jacobs, \& Harold, 1990; Jenckes \& Phillips, 1998; Sadker \& Sadker, 1994). Specifically, this research purports that these students may suffer negative performance outcomes due to a lingering burden by the potential of conforming to negative cultural stereotypes challenging their academic abilities. This particular burden is what researchers have labeled as "stereotype threat." When negative stereotypes about particular groups are made salient to individuals who belong to those groups, a situational pressure is placed on that individual, which decreases his or her ability to perform well. This phenomenon can be experienced as a physiological arousal that often results in lower performance on intellectual and academic tasks (Spencer et al., 1999; Steele \& Aronson, 1995). Results of a study by Steele and Aronson (1995) revealed that inducing stereotype threat- i.e., notifying test takers that a test measures intellectual ability and asking them to provide their race before the test, significantly lowered African American students' performance on intellectual tasks. In contrast, reducing stereotype threat- i.e., by reassuring test takers that the test is not going to be used to measure intellectual abilities, significantly improved African American students' test performance. Steele (1998) clarified that individuals need not believe the particular stereotype of their cultural 
group but rather are introduced to a negative stereotype which they end up contending with during a test situation.

Research indicates that there are two general factors that contribute to stereotype threat (Inzlicht \& Ben Zeev, 2000). The first factor is evaluative scrutiny. The potential of being skeptically evaluated in a stereotyped domain is a significant trigger to key responses associated with stereotype threat, such as lack of enjoyment of educational processes, increased anxiety and stress, and lowered ability and performance. The second factor is group composition. This refers to the racial and gender mix in the test taking environment that can trigger stereotype-relevant thoughts. Group composition can make salient one's own cultural identity and the stereotypes associated with it.

By integrating stereotype threat research with achievement research, Ryan and Ryan (2005) provide a proposed model (Figure 1) illustrating the comprehensive framework of the association of motivational, affective, and cognitive processes with stereotype threat and test performance. 


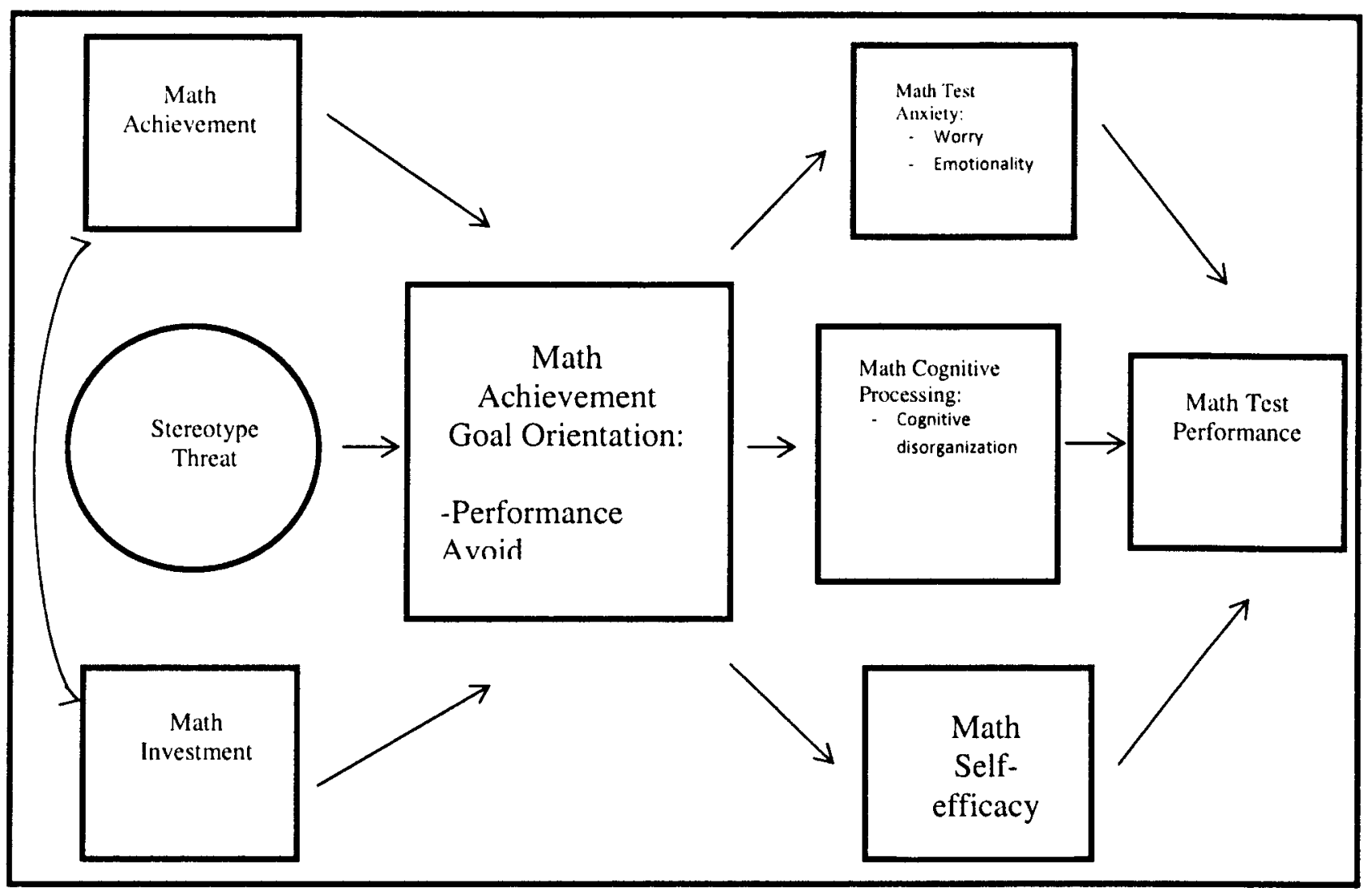

Figure 1. Conceptual model of psychological processes underlying Stereotype Threat and standardized math test performance (Ryan, 2005).

To summarize the conceptual framework, African American students who are invested in their mathematics test performance will be susceptible to stereotype threat in a high stereotype-threat situation such as being in a classroom in which they are one of few other African American students, and in which perceptions of lower expectations are received from their teacher. Concerns about fulfilling a negative stereotype (i.e. "Blacks do not do well in math") may then bring about a performance-avoidance goal orientation towards the test-taking situation. A performance-avoidance goal may then lead to an 
increase in worry and test anxiety, make self-efficacy vulnerable, resulting in the disorganization or diminishing of cognitive abilities. As a consequence, mathematics test performance may be lowered for students in a high stereotype threat situation (Ryan \& Ryan, 2005).

\section{Educational Resiliency Theory}

\section{Educational Resiliency}

Academic resilience may be defined as "the process and results that are part of the life story of an individual who has been academically successful, despite obstacles that prevent the majority of others with the same background from succeeding" (Morales \& Trotman, 2004, p. 8). The theory of resiliency is developed from a combination of developmental psychology, psychiatry, and clinical psychology research, and attempts to account for adverse outcomes among individuals exposed to at-risk environments (Griffin \& Allen, 2006). Another definition provided for educational resilience is the "heightened likelihood of success in school and in other aspects of life, despite environmental adversities, brought about by early traits, conditions, and experiences" (Wang, Haertel, \& Wahlberg, 1995, p. 5). Resilient students seem to be able to take difficult environments and somehow translate them into a source of motivation. Resilience can exist as a reaction to a specific event or be a broader response to high-risk environments an individual may be exposed to throughout life.

\section{African American Students and Educational Resiliency}

With the educational success of African American school children falling behind that of their White counterparts, researchers have been led to inquire on details surrounding these trends. As previously mentioned, one assumption is that negative 
attitudes that African American school children may have toward school and their academic achievement may affect their scholastic performance (Fordham \& Ogbu, 1986; Jencks \& Phillips, 1998). However, more recent research does not support this (Cook \& Ludwig, 1998; Fryer \& Torelli, 2005; Tyson, 2002). There have been studies, like the previous, that have resulted in the opposite. For example, Wilson and Corbett (2001) found that middle school urban African American students reported high academic achievement expectations regardless of the low-performing school they may have attended. They purported that adversarial (or negative) attitudes are not as prevalent among African Americans as previous research has suggested and these students may present more resilience than expected. Although much of the research around educational resilience in African American students has focused on students at the middle and high school levels, Lewis and Kim (2008) conducted research this construct among elementary-aged African American children. The results of their study reflected that most of the students expressed enthusiastic and positive attitudes toward learning regardless of adverse conditions that may have existed. Students displayed a persistent desire to learn. Their responses also suggested that the quality of the student-teacher relationship was very important to how they perceived their entire academic experience.

For many African American students, academic success may rest upon their ability to be resilient in the face of racism, poverty, lack of resources, and other societal factors (Griffin \& Allen, 2006). For example, in one study a group of low-income African American students from an urban school used their knowledge of the struggle of African Americans as a motivator that pushed them towards achieving their college goals (O’Connor, 1997). In another study comparing resiliency of African American students 
from one school lacking academic resources and another highly resourced school, results showed that despite any barriers encountered by students at either schools, they were not dissuaded from their college goals. Students from both schools reported high long-term educational aspirations and anticipated being educated even beyond a bachelor's degree (Griffin \& Allen, 2006).

In studying educational attitudes and motivation in Black South African high school students, Watson and Stead (1997) found that $84 \%$ of the students in their study were concerned about failing or achieving low grades. However, $67 \%$ felt they could resist peer pressure that might prevent them from studying. Though the overall results of the study demonstrated that students displayed negative feelings associated with school and studying, there were conflicting results that revealed that students may also possess resilience in academic situations as previous research has purported (Dass-Brailsford, 2005; Lewis \& Kim, 2008; Tyson, 2002; Watson \& Stead, 1997; Wilson \& Corbett, 2001).

Similarly, Tyson (2002) examined attitudes of African American young children towards school. Results of this study revealed that African American students were eager to participate in class fully and showed a sense of pride when it came to their academic success. Additionally, whereas research has suggested that older African American students often ridicule and ostracize their peers for high academic achievement, the younger students in Tyson's study ridiculed each other for low academic performance. Overall, the students expressed excitement as opposed to negative attitudes toward learning and school. Academic resilience may rest as the contributing factor to results such as Tyson's (2002) and Lewis and Kim's (2008). 


\section{Educational Resiliency in Context}

In discussing academic resiliency, it is equally important to understand factors that may affect resiliency among African American students. In one study of Black South African students, results revealed that with regards to resiliency there are two main frameworks: (a) factors that are experienced as stressors on resiliency of students and (b) factors that were experienced as supportive of their resiliency. Factors identified as stressors included poverty, lack of educational resources, and violence. Factors associated with support included individual characteristics (goal-orientation, motivation, agency), familial characteristics (atmosphere, support, structure, spirituality, role modeling), and schools and communities (school resources and support and teacher characteristics; DassBrailsford, 2005). Thus, teacher characteristics, including their perceptions of students, may act in one of two ways: as a stressor hindering resiliency (such as a teacher displaying negative perceptions that lead to the internalization of harmful stereotypes) or as a support developing resiliency (such as a teacher displaying positive perceptions that aid in combating existing negative stereotypes).

\section{Teacher Attitudes and Belief as Contributors to Resiliency}

Teachers themselves may play an important role in the attitudes and achievement of students (Lewis, 1995); therefore, it is equally imperative to understand teacher perceptions and the student-teacher relationship also. Love (2001) examined the relationship between teachers' beliefs and student achievement of urban African American students and discovered that there were two factors regarding teachers' beliefs that explained a significant amount of the variance in achievement and positive attitudes in students. These two factors were cultural congruence (valuing both cultural identities 
and critical thinking as a way to make educational content meaningful to students) and poor learner support (identifying and using strategies that are meant to specifically help lower-achieving students succeed).

\section{Teacher Style as Contributor to Resiliency}

What and how students are taught may affect their achievement and attitudes. Low achievers are particularly at risk for possessing lower academic self-concept. Research has indicated a perpetual interaction between self-concept and academic achievement (Beane \& Lipka, 1987). African American elementary students' perception of what influences their academic achievement and their particular learning styles may affect their academic success (Wilson-Jones \& Caston, 2004). It is important that teachers of African American students understand the role of culture on their learning styles. Research has found that African American children engage better in people-oriented tasks such as collaborative work within groups (Hale-Benson, 1982) and that it is important for African American children to feel a sense of accomplishment when it comes to academic pursuits (Edwards \& McMillion, 2000; Justice, 1999). This sense of accomplishment can foster academic self-esteem and self-concept in African American males in particular (Justice, Lindsey, \& Morrow, 1999). These results provide implications as to what type of academic instruction is better received by African American students and how teacher actions, which are affected by teacher beliefs, can influence students' academic achievement and attitudes.

Moreover, understanding how students perceive not only their learning environment but also their teachers can provide itself useful in unveiling students' challenges and barriers from being educationally successful and perceiving academics 
positively (Howard, 2001). As mentioned previously, research has supported that students, even at a young age, have the ability to understand their unique learning environment (Bloom, 2008). More specifically, African American students at even a young age may have the capacity to perceive and be affected by their teacher's ability to provide culturally relevant teaching. Culturally relevant instruction reflects and embraces the role that cultural socialization plays in how students receive, analyze, and understand information (Allen \& Boykin, 1992; Au \& Jordan, 1981; Cazden \& Leggett, 1981). Research on this subject matter may have essential implications for ethnic minority students, particularly African American students whose cultural socialization may play an important part in learning experiences. Research in one particular study revealed that the three attributes mentioned most frequently by students were their teacher's willingness to show care for them, their teacher's ability to structure their classroom in a way that embraced the student's home or community, and their teacher's ability to make education and the learning process fun and exciting. Though students did not directly mention practices or norms that are associated specifically with African American culture, the student's characterizations of their teachers reflected the desire for culturally relevant instruction (Howard, 2001).

Additionally, a growing concern has developed about the disintegration of students' achievement-related beliefs, values, and attitudes after the transition to middle school (Midgley et al., 1989). Student-teacher relationships have been shown to deteriorate after the transition from elementary school to middle school. Specifically, students feel that the mathematics teachers they had in middle school cared less about them compared to those they had in elementary school (Midgley et al., 1988). In addition 
to this, research on the effects of classroom climate suggests that the quality of the student-teacher relationship is associated with students' motivation and attitudes toward school (Berndt \& Hawkins, 1988; Fraser \& Fisher, 1982; Hartmut, 1978; Moos, 1979; Trickett \& Moos, 1974). Moreover, various groups of students may be affected more than others by the quality of their relationship with their teachers. Also, high and low achieving students may be affected differently (Midgley et al., 1989). In one study differences in perceived teacher support resulted in significant differences in the student's valuing of mathematics. In addition, high-achieving students valued mathematics more than low-achieving students. Results supported the researchers' hypothesis that changes in students' valuing of mathematics were associated with differences in perceived teacher support between the transition from elementary school to junior high school (Midgley et al., 1989). Results also revealed that when students perceived their teacher as high in support, their perceptions of the value and usefulness/importance of mathematics change very little from the first semester to the second. The opposite affect occurs for students who perceived their teacher as low in support. Their perceptions declined within the year. Overall, the findings of this study indicate that the value of mathematics increases for students who move from less supportive to more supportive teachers after the transition and decreases for students who experience the opposite. This supports the need for further research on what factors affect mathematics attitudes at both the elementary and middle school levels and the role teachers play.

Research has shown that teachers potentially play an important role in the resiliency of students. In one study a common factor that contributed to at-risk students staying in school was having teachers who expressed confidence in them (Lewis, 1995). 
Students also view their teachers as key contributors to academic support systems by existing as a positive role model and providing encouragement. For students in urban schools especially, teacher mentors often play crucial parts in students' success or failure. This is due in part to the limited exposure these students may have to other academic role models (Dass-Brailsford, 2005).

\section{Rationale for Studying the Association of Cultural Minorities and Academic Achievement}

As previously mentioned, academic and educational gaps among ethnic groups have long troubled our society. With African American students making up less than 10\% of admissions to 4-year colleges and scoring substantially lower than Whites on mathematical portions of standardized tests, a growing concern for a better understanding and for the development of new strategies to prevent this negative trend has developed (Roach, 1999). Some scholars suggest that factors surrounding ethnicity and racial experiences, such as negative expectations and stereotypes, may play a role in the education of some students (Ferguson, 2003; Garabaldi, 1992; Spencer et al., 1999; Steele \& Aronson, 1995).

In studying the relationships between ethnic variables and students' education, it is equally important to assess how teachers may perceive race-related factors. In one study, teacher attitudes towards Whiteness and White privilege were examined through the lens of Critical Race Theory (Vaught \& Castagno, 2008). Critical Race Theory purports that racism is pervasive, is permanent, and must be challenged (Bell, 1992; Bernal, 2002; Crenshaw, Gotanda, Peller, \& Thomas, 1995; Delgado \& Stefancic, 2001; Ladson-Billings \& Tate, 1995; Lynn, Yosso, Solorzano, \& Parker, 2002; Tate, 1997). 
This study revealed that awareness did not lead to empathy among teachers. It also revealed that the school districts lacked in developing institutional change in challenging racist points of views.

In sum, the results of previous literature provide reason as to why research surrounding factors associated with ethnicity regarding education is important. In addition to this, the widening achievement gap between ethnic minority, particularly African American, and White students remains a reality yet a mystery to solve nationwide. This mystery of a solution and of a better understanding is what propels researchers to further examine differences that exist among cultural groups within our society.

\section{Summary}

In conclusion, though the educational gap between African American students and White students has somewhat narrowed, African American students still underperform in academic areas, including mathematics, compared to White students. This study aims at understanding factors related to this underperformance of African American students. Due to the historical connection between educational attitudes and academic performance (that being believed to be a positive relationship), individuals have been left to assume that African American students do not perform well in subjects such as mathematics due to not having positive attitudes of enjoying and perceiving themselves well. This may be caused by negative expectations through racial and ethnic stereotypes. These negative expectations in an academic setting often can be displayed through teachers to students whom they believe do not enjoy or perceive themselves highly in the academic subject they teach. Supporting stereotype threat theory, these 
negative expectations and perceptions can be perceived and internalized by students causing students to experience stress in response to thinking about stereotypes related to their racial group. Much research in the past has focused on the relationship between negative expectations and stereotypes and underperformance, disengagement, or negative educational attitudes of African American students. However, more recent research focuses on looking at African American students who do have positive academic experiences regardless of negative stereotypes, and what factors aid and affect this resiliency. The current study specifically aims at discovering how predominantly White teachers perceive the mathematics attitudes of African American students and how the mathematics attitudes of African American elementary students compare to their White counterparts. 


\section{CHAPTER THREE \\ METHODS}

This chapter will discuss the methodology for the study. The subjects studied are described, the instruments used are reviewed, the procedures for the study are delineated, the research questions initiating the study are discussed, and the ethical considerations are explained.

\section{Subjects}

This study was conducted on a convenience sampling from a larger study of students in three school districts in Kentucky. One school district was urban, one was suburban, and one was rural. The sample consisted of 1,429 self-identified White American and African American third, fourth-, and fifth-, and sixth grade students (approximately 9 to 12 years old) in a total of 71 mathematics classes at 9 elementary and middle schools. Students who identified as non-White and non-African American were eliminated from the data due to the study's intended purpose of comparing experiences of White and African American students specifically. All students present on the day of the survey administration were included, and no attempt to survey absent students was made. As shown in Table 1, the current study sample consisted of 1,216 White students $(650$ girls and 566 boys) and 213 African American students (121 girls and 92 boys). Most of the teachers in the current study identified as White and female. An attempt to survey 
absent teachers was made by help of the principal(s) at the school(s) and by email. Table 1 provides detail of the sample population.

Table 1

Sample Population by Grade Level, Ethnicity, and Gender

\begin{tabular}{|c|c|c|c|c|c|c|}
\hline \multirow[b]{2}{*}{ Ethnicity } & \multicolumn{3}{|c|}{$N$} & \multicolumn{3}{|c|}{$\%$} \\
\hline & Girls & Boys & Total & Girls & Boys & Total \\
\hline $\begin{array}{c}\text { White } \\
\text { American }\end{array}$ & 650 & 566 & 1216 & 53.5 & 46.5 & 85.1 \\
\hline $\begin{array}{c}\text { African } \\
\text { American }\end{array}$ & 121 & 92 & 213 & 56.8 & 43.2 & 14.9 \\
\hline Total & 771 & 658 & 1429 & 54.0 & 46.0 & 100.0 \\
\hline
\end{tabular}

\section{Review of Instruments}

Three researchers administered a paper-and-pencil survey to students. The Math and Me Survey (Adelson, 2006) is designed specifically to measure third- through sixthgraders' attitudes towards mathematics (Appendix A). This instrument consists of 18 five-point Likert items that make up two scales: Mathematical Self-Perceptions and Enjoyment of Mathematics (Adelson \& McCoach, in press). For each scale, the researcher calculates a score by averaging the responses to all items. This instrument was initially piloted with a sample of 1,043 students. The validation sample resulted in a 
reliability coefficient (Cronbach's alpha) for the Enjoyment of Mathematics scale of .939 and for the Mathematical Self-Perception scale of .917. The current sample resulted in a reliability coefficient for the Enjoyment of Mathematics scale of .934 and for the Mathematics Self-Perception scale of .899. The reliability coefficients for African American students were .921 and .897 for the enjoyment and self-perceptions scale, respectively. The reliability coefficients for White students were .935 and .900 for the enjoyment and self-perceptions scales, respectively. At the end of the survey, students reported their demographic information (sex, grade level, and ethnicity).

While students were completing the survey, their teachers completed a researcherdeveloped Teacher Questionnaire (Appendix B) on which they were prompted to categorize, according to their perceptions, each of their students' level of mathematical enjoyment, self-perceptions, and mathematics and reading ability. Responses were made on a 1-5 point scale ( 1 signifying as low and 5 signifying as high). Teachers were given a specific definition of each point category to ensure adequate scoring. Teachers were also

asked to provide demographic information surveying their ethnicity, years of teaching, and degree level, and whether the class was considered gifted and/or ability grouped.

\section{Procedures for the Study}

Before administering surveys, approval was received from the school districts. The study complied with relevant ethical standards and was exempted from formal review by the University of Louisville Human Subjects and Institutional Review Board. Principals at the participating schools were contacted and gave written permission for the conducting of the study at their schools. 
Each survey was coded with a particular number that was located at the top of the survey. The first digit indicated the district, the second reflected the school, the third digit reflected the mathematics teacher, and the final two digits indicated the student in the class. In addition to this, each survey had a form attached to it with a code identical to the student code found on the survey. Students wrote their name on this form so that teachers could identify each student when completing their Teacher Questionnaire. Student names were only provided on these blank forms. The surveys were completely anonymous. These coded name forms were left with each principal to be shredded and destroyed to ensure confidentiality. This coding allowed researchers to connect the students' Math and Me Survey scores with the teachers' ratings of the students while keeping each student's survey and teacher ratings anonymous.

At least one member of the research team visited each classroom and administered the surveys. An introduction of the survey, information about the research, and the purpose of the study were given. This was followed by an explanation of confidentiality of student responses and voluntary participation. Each student completed and turned in the coded name form, and then the researcher proceeded to administer the survey by reading the directions to the students and going through each item on the survey aloud (including the demographic section at the end). For higher ability classes (predominantly fifth- and sixth-grades), only instructions were read aloud; this decision was made by the teachers. While students completed the survey, the researcher was available to answer any questions the students had.

While students completed the Math and Me Survey, the teachers completed the Teacher Questionnaire. Teachers were given a document that had their demographic 
questionnaire on the front and a chart on the back which listed the coded numbers that corresponded with each student survey and sections for teachers to categorize (according to their perceptions) each code (student) from 1 to 5 on students' mathematics enjoyment, mathematics self-perceptions, mathematics ability, and reading ability. Teachers were also given the coded name forms that the students completed so that they could identify which code corresponded with which student so that they could complete the chart.

Once all 9 schools had been surveyed, the data from the student instrument and both of the Teacher Perception forms were compiled into one database for further analysis. 


\section{Research Questions}

This study aims to determine the following for African American elementary students in comparison to their White counterpart and in relation to their teachers and learning environment:

1. A) Do overall differences exist between African American and White elementary students on their mathematics enjoyment and on their selfperceptions of their mathematics ability?

B) Do overall teacher ratings of student self-perceptions and enjoyment differ for African American and White students?

2. A) How do teacher ratings of African American students' mathematics ability, enjoyment, and self-perceptions correlate with student ratings of their own mathematics enjoyment and self-perceptions?

B) How do these correlations compare to the same correlations for White students?

3. A) Do differences exist between teacher-rated attitudes and student-rated attitudes?

B) If differences do exist, are they the same for African American and White American students?

For teacher ratings, mathematics ability and attitudes were analyzed through the teacher's perceived ability of the students and their perceptions of the each student's rating of enjoyment and self-perceptions. For student ratings, each student provided their own self-report of their mathematical enjoyment and self-perceptions. 


\section{Hypotheses}

The hypothesis for this study is that teachers will rate African American students significantly lower on their mathematics enjoyment and self-perceptions compared to White students regardless of the existence or non-existence of significant differences between African American and White students on these measures.

For the purposes of this study, results showing teachers rating African American students significantly lower than White students and African American students rating themselves significantly lower than White students on mathematics enjoyment and selfperceptions may partially support aspects of Stereotype Threat Theory. These results would suggest that teachers rating African American students lower may resemble remnants of possible stereotypes, and if these students do in fact enjoy and perceive themselves at lower rates than White students, this may reflect possible negative effects of these stereotypes.

In the context of this study, results supporting Resiliency Theory would reflect teachers rating African American students significantly lower than White students; however, African American students rating themselves at the same level or higher than White students on mathematics enjoyment and self-perceptions. Results of teachers rating African American students significantly lower would again resemble effects of possible stereotypes; moreover, these students enjoying and perceiving themselves in mathematics at the same or higher rate as White students may reflect the existence of certain barriers that aid in them being resilient regardless of the negative expectations and beliefs of their teachers. 


\section{Data Analysis}

Once data were entered into SPSS, the researcher calculated descriptive statistics. These statistics included correlations, difference scores, and an Analysis of Variance (ANOVA). The first step in analyzing the data was to look at preliminary differences found between African American and White students. The data file was split by ethnicity and an Analysis of Variance (ANOVA) was run for main variables of student selfperceptions and student mathematics enjoyment based on ethnicity. Next, an ANOVA was conducted to evaluate if statistically significant differences existed between African American and White students on teacher-rated attitudes and if this difference was positive or negative.

In the next step in analyzing the data, relationships between teacher variables and students' variables were looked at more closely to examine significant correlations and differences between teachers' ratings of students and students' ratings of themselves on mathematics enjoyment and self-perceptions. First, the data were split according to ethnicity and Pearson's $r$ was used to examine correlations between teacher ratings and student ratings. Second, because each student was presented with an average self-score and teacher score of mathematics self-perceptions and enjoyment, each student's average score was subtracted from his or her teacher's perceived score to create what is termed a "difference score". ANOVAS were then conducted on difference scores for both selfperceptions (self-perception difference score) and enjoyment (enjoyment difference score) comparing ethnicity. According to Thomas and Zumbo (2011), "if difference scores make sense from a subject matter perspective, and if the corresponding analysis is likely to have appropriate power, there is no reason to avoid their use" (p. 7). 


\section{Limitations of the Study}

One of the limitations of this study is that it uses a convenience sample. Although several schools within each school district were surveyed, it is impossible to capture the essence of the entire district without surveying every school. Schools that responded with the willingness to help with this study were chosen. As a result, many schools were not included that may have provided a broader and more reflective sample.

In addition to this, the gap between the sizes of the total number of African American students to White students in the sample is unfortunately very large with White students existing as the greater portion of the overall sample. Because of this African American students may have been underrepresented in this sample leading to biased results. However, having a lower number of African American students was expected prior to conducting the study due to the geographic area in which the research was conducted. Moreover, as mentioned previously, group composition can have effects on how African American students experience stereotypes; therefore, having several classrooms in which African American students made up a small portion of overall students may reflect normal experiences of African American students in these types of settings.

Not only were African American students underrepresented, but student's reports of their racial and ethnic background were given as a self-identified report. With children of young ages often not fully understanding or being knowledgeable of their ethnic background, this can present issues with how these factors are reported. In fact, when the researchers were administering the surveys, a number of students commented that they did not know how to respond to the ethnicity question. 
Another limitation comes with doing survey based research especially with children. Survey based research requires researchers to depend on the reports of individual's feelings, attitudes, and experiences which can be falsely or erroneously

presented. This can be the case when working with children in particular because they often times display social desirability where they may answer how they believe the researcher or their teacher would want them to respond.

\section{Summary}

This chapter explored the methodology of the current study including details surrounding subjects, instruments, procedures, research questions, hypotheses, data analyses and study limitations. The next chapter will provide statistical results of the current study including preliminary cross-racial comparisons, comparisons across ethnicity on student variables and teacher variables, and looking in depth at studentteacher variable relationships and student-teacher variable differences. 


\section{CHAPTER FOUR}

\section{RESULTS}

The results are presented in sections based on descriptive information for the sample and on the proposed research questions of the study. The proposed research questions were as follows:

1. A) Do overall differences exist between African American and White elementary students on their mathematics enjoyment and on their selfperceptions of their mathematics ability?

B) Do overall teacher ratings of student self-perceptions and enjoyment differ for African American and White students?

2. A) How do teacher ratings of African American students' mathematics ability, enjoyment, and self-perceptions correlate with student ratings of their own mathematics enjoyment and self-perceptions?

B) How do these correlations compare to the same correlations for White students?

3. A) Do differences exist between teacher-rated attitudes and student-rated attitudes?

B) If differences do exist, are they the same for African American and White American students? 


\section{Descriptive Results}

\section{Mathematics Enjoyment}

Table 2 shows descriptive information for Mathematics Enjoyment. For this variable there was an overall sample of 1,372 students with 201 students being African American and 1,171 White students. As shown in the table, White students had a lower mean score and were more variable in their enjoyment of mathematics. The range of scores for African American students was slightly smaller than that of White students.

\section{Mathematics Self-Perceptions}

Table 2 shows descriptive information for Mathematics Self-Perceptions. There was an overall sample of 1,386 students with 204 African American students and 1,182 White students. The mean score for Whites was only slightly less than the mean for African Americans, who were more variable but had the same minimum and maximum score as White students.

\section{Teacher Rating of Mathematics Enjoyment}

Table 2 shows descriptive information for Teacher Ratings of Mathematics Enjoyment. For this variable there was an overall sample of 1,421 students with 212 African American students and 1,209 White students. The mean score for the teacher ratings of enjoyment for Whites was higher than that for African American students. These ratings for White students were also less variable than for African American students with the same minimum and maximum scores.

\section{Teacher Rating of Mathematics Self-Perceptions}

Table 2 shows descriptive information for Teacher Ratings of Mathematics SelfPerceptions. For this variable there was an overall sample of 1,421 students with 212 
African American students and 1,209 White students. The mean score for White students on teacher ratings of mathematics self-perceptions was higher than that of African American students. This mean score was also slightly more variable than that for African American students. Both White and African American students had equal minimum and maximum scores.

\section{Difference Scores of Mathematics Enjoyment}

Table 2 shows descriptive information for the Difference Scores of Mathematics Enjoyment. For this variable there was an overall sample of 1,364 students with 200 students being African American and 1,164 White students. The mean for White students on the mathematics enjoyment difference score was higher than the mean difference score for African American students. White students also varied much more than African American students on this difference score. Compared to White students, African American students had a lower range of difference scores having both lower minimum and maximum scores

\section{Difference Scores of Mathematics Self-Perceptions}

Table 2 shows descriptive information for the Difference Score of Mathematics Self-Perceptions. For this variable there was an overall sample of 1,378 students with 203 African American students and 1,175 White students. The mean for White students on mathematics self-perceptions difference score was higher than that of African American students. However, African American students were more variable on this difference score with a smaller range of scores. African American students had a higher minimum, yet lower maximum for this difference score. 
Table 2

Descriptive Statistics by Variable

\begin{tabular}{|c|c|c|c|c|c|c|c|c|c|}
\hline \multirow[b]{2}{*}{ Scale } & \multicolumn{3}{|c|}{ Total } & \multicolumn{3}{|c|}{ White } & \multicolumn{3}{|c|}{ African American } \\
\hline & $N$ & $\begin{array}{c}\text { Mean } \\
(S D)\end{array}$ & Range & $N$ & $\begin{array}{c}\text { Mean } \\
(S D)\end{array}$ & Range & $N$ & $\begin{array}{c}\text { Mean } \\
(S D)\end{array}$ & Range \\
\hline $\begin{array}{l}\text { Math } \\
\text { Enjoyment }\end{array}$ & 1372 & $3.59(1.00)$ & $\begin{array}{l}1.00 \\
5.00\end{array}$ & 1171 & $3.55(1.01)$ & $\begin{array}{l}1.00- \\
5.00\end{array}$ & 201 & $3.81(0.94)$ & $\begin{array}{l}1.20- \\
5.00\end{array}$ \\
\hline $\begin{array}{l}\text { Math Self- } \\
\text { Perceptions }\end{array}$ & 1386 & $3.71(0.81)$ & $\begin{array}{l}1.00 \\
5.00\end{array}$ & 1182 & $3.71(0.80)$ & $\begin{array}{l}1.00- \\
5.00\end{array}$ & 204 & $3.76(0.83)$ & $\begin{array}{l}1.00- \\
5.00\end{array}$ \\
\hline $\begin{array}{l}\text { TR } \\
\text { Enjoyment }\end{array}$ & 1421 & $3.59(0.99)$ & $\begin{array}{l}1.00- \\
5.00\end{array}$ & 1209 & $3.65(0.97)$ & $\begin{array}{l}1.00- \\
5.00\end{array}$ & 212 & $3.22(1.00)$ & $\begin{array}{l}1.00- \\
5.00\end{array}$ \\
\hline $\begin{array}{l}\text { TR Self- } \\
\text { Perceptions }\end{array}$ & 1421 & $3.43(1.01)$ & $\begin{array}{l}1.00- \\
5.00\end{array}$ & 1209 & $3.50(1.00)$ & $\begin{array}{l}1.00- \\
5.00\end{array}$ & 212 & $3.04(0.98)$ & $\begin{array}{l}1.00- \\
5.00\end{array}$ \\
\hline $\begin{array}{l}\text { Enjoyment } \\
\text { Diff }\end{array}$ & 1364 & $0.00(1.18)$ & $\begin{array}{c}-3.90- \\
3.90\end{array}$ & 1164 & $0.10(1.15)$ & $\begin{array}{c}-3.70- \\
3.90\end{array}$ & 200 & $0.59(1.19)$ & $\begin{array}{c}-3.90- \\
2.60\end{array}$ \\
\hline $\begin{array}{l}\text { Self-Percep } \\
\text { Diff }\end{array}$ & 1378 & $0.27(1.02)$ & $\begin{array}{l}-3.25- \\
3.13\end{array}$ & 1175 & $\begin{array}{c}- \\
0.20(1.00)\end{array}$ & $\begin{array}{c}-3.25- \\
3.13\end{array}$ & 203 & $0.72(1.05)$ & $\begin{array}{c}-3.00- \\
3.00\end{array}$ \\
\hline
\end{tabular}

\section{Analyses by Research Questions}

\section{Do overall differences exist between African American and White}

elementary students on their mathematical enjoyment and on their self-perceptions of their mathematical ability?

For cross-racial comparisons of student variables, a one-way ANOVA was conducted. The Levene's Test for the ANOVAs were not statistically significant for mathematics enjoyment $F(1,1370)=2.15$, ns or mathematics self-perceptions, $F(1$, $1384)=.040, n s$, indicating that the group variances for the sample are equal (i.e., not violating the assumption of homogeneity of variance). Table 3 presents the results of the 
ANOVAs. For mathematics enjoyment, there was a statistically significant difference between African American and White students, with African American students $(M=$ $3.81)$ reporting enjoying mathematics at a higher rate than their White counterparts $(M=$ 3.55), $F(1,1370)=11.07, p<.01, \omega=.085)$. On the other hand, African American students $(M=3.76)$ reported non-statistically significant, and therefore similar, mathematical self-perceptions compared with their White peers $(M=3.71), F(1,1384)=$ $.798, p>.05, \omega=.036$ ). The effect size for mathematics enjoyment reflected a medium to large effect (Field, 2009), while the effect size for mathematics self-perceptions reflected a small to medium effect. Figure 2 visually shows a graph of differences between White and African American students in their enjoyment of mathematics and their mathematics self-perceptions.

Table 3

Summary of ANOVA for Mathematics Enjoyment and Self-Perceptions

\begin{tabular}{|c|c|c|c|c|c|c|c|}
\hline & & $\begin{array}{l}\text { Sum of } \\
\text { squares }\end{array}$ & $d f$ & $\begin{array}{c}\text { Mean } \\
\text { square }\end{array}$ & $F$ & $p$ & $\Omega$ \\
\hline \multicolumn{8}{|l|}{ Enjoyment } \\
\hline & Between groups & 11.07 & 1 & 11.07 & $11.08 * *$ & .001 & .085 \\
\hline & Within groups & 1368.36 & 1370 & .999 & & & \\
\hline & Total & 1379.43 & 1371 & & & & \\
\hline \multirow{2}{*}{\multicolumn{8}{|c|}{$\begin{array}{l}\text { Self- } \\
\text { Perceptions }\end{array}$}} \\
\hline & & & & & & & \\
\hline & $\begin{array}{l}\text { Between } \\
\text { Groups }\end{array}$ & .521 & 1 & .521 & .798 & .372 & .036 \\
\hline & Within Groups & 904.86 & 1384 & .654 & & & \\
\hline & Total & 905.38 & 1385 & & & & \\
\hline
\end{tabular}

$* * p<.01$ 


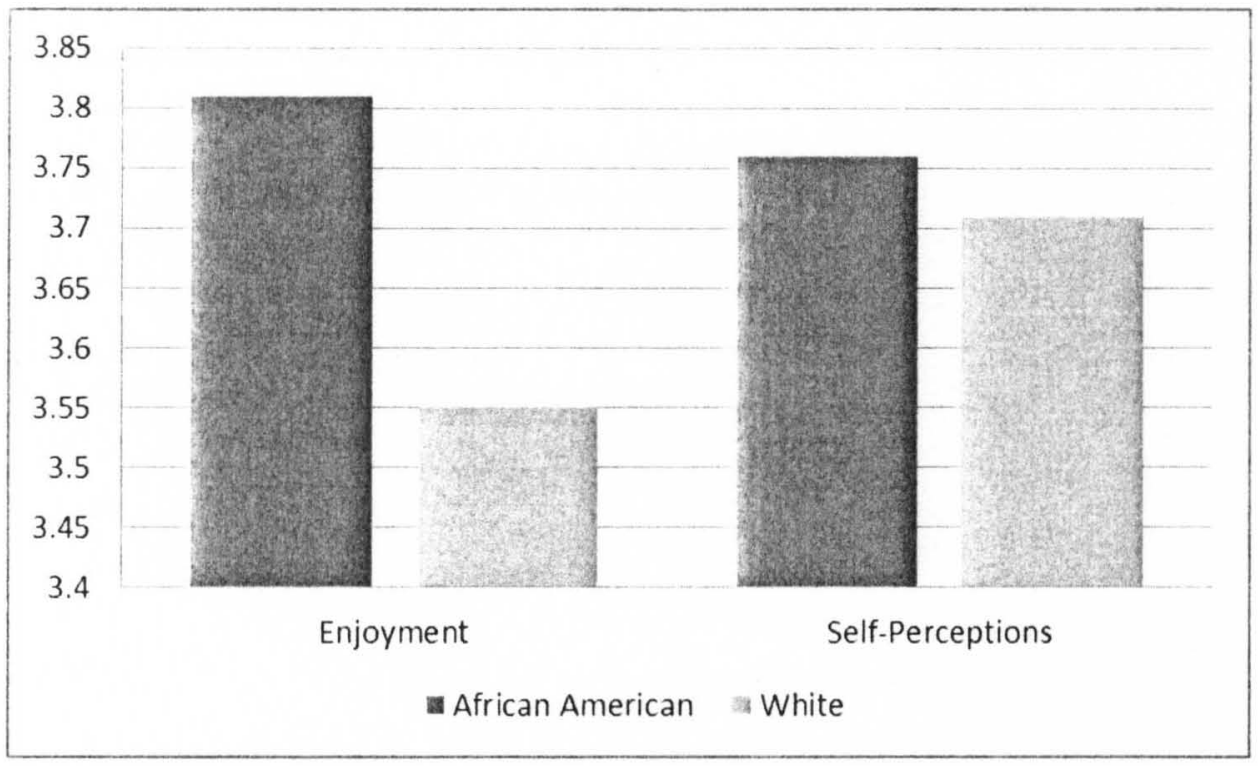

Figure 2. Comparison of White and African American sutdents on Mathematics Enjoyment and Mathematics Self-Perceptions.

\section{Do overall teacher ratings of student self-perceptions and enjoyment differ}

\section{for African American and White students?}

For cross-racial comparisons of teacher variables, a one-way ANOVA was conducted. For teacher ratings of student enjoyment the Levene's Test was not statistically significant, $F(1,1419)=.371, n s$, indicating that the group variances for the sample are equal (i.e., not violating the assumption of homogeneity of variance). However, the Levene's Test for teacher ratings of student mathematics self-perceptions was significant, $F(1,1419)=11.75, p<.01$. Group variance differences were examined closer by looking at the group variance ratios. The largest to smallest group variance ratio was less than two and close to one for this variable, reflecting small differences between group variances. According to Field (2009), "in large samples, the Levene's test can be significant even when group variances are not very different" (p. 152). In addition to this, for this variable, the group (White students) with the larger group size was also the group 
with the larger variance. Having two groups with unequal sample sizes and with the largest group producing the largest variance will result in the actual $\alpha$ being less than the nominal $\alpha$, making the Levene's statistical test slightly more conservative (Glass \& Hopkins, 1996). As shown in Table 4, cross-racial comparisons of teacher variables through ANOVAs revealed statistically significant differences between teachers' ratings of student mathematics enjoyment, $F(1,1419)=33.24, p<.01, \omega=.153$, and selfperceptions, $F(1,1419)=37.93, p<.01, \omega=.160$ for African American students compared to White students. For enjoyment and self-perceptions teachers rated White students $\left(M_{\text {enjoyment }}=3.65, M_{\text {selfperceptions }}=3.50\right)$ statistically significantly higher than African American $\left(M_{\text {enjoyment }}=3.22, M_{\text {selfperceptions }}=3.04\right)$ students. The effect size for both teacher ratings of enjoyment and self-perceptions represented relatively large effects (Field, 2009). Figure 3 visually shows a graph of differences between teacher ratings of White and African American students' mathematics self-perceptions and enjoyment of mathematics.

Table 4

Summary of ANOVA for Teacher Rating of Self-Perceptions and Enjoyment

\begin{tabular}{llrrrrrr}
\hline & & $\begin{array}{c}\text { Sum of } \\
\text { squares }\end{array}$ & Df & Mean & & \\
& & square & $F$ & $P$ & $\Omega$ \\
\hline TR Self- & Between Groups & 37.56 & 1 & 37.57 & $37.93^{* *}$ & .000 & .160 \\
Perceptions & & & & & & \\
& Within Groups & 1404.87 & 1419 & .990 & & & \\
& Total & 1442.42 & 1420 & & & & \\
TR Enjoyment & Between Groups & 33.24 & 1 & 33.24 & $34.95^{* *}$ & .000 & .153 \\
& Within Groups & 1349.28 & 1419 & .951 & & & \\
& Total & 1382.52 & 1420 & & & & \\
\hline
\end{tabular}

$* * \mathrm{p}<.01$ 


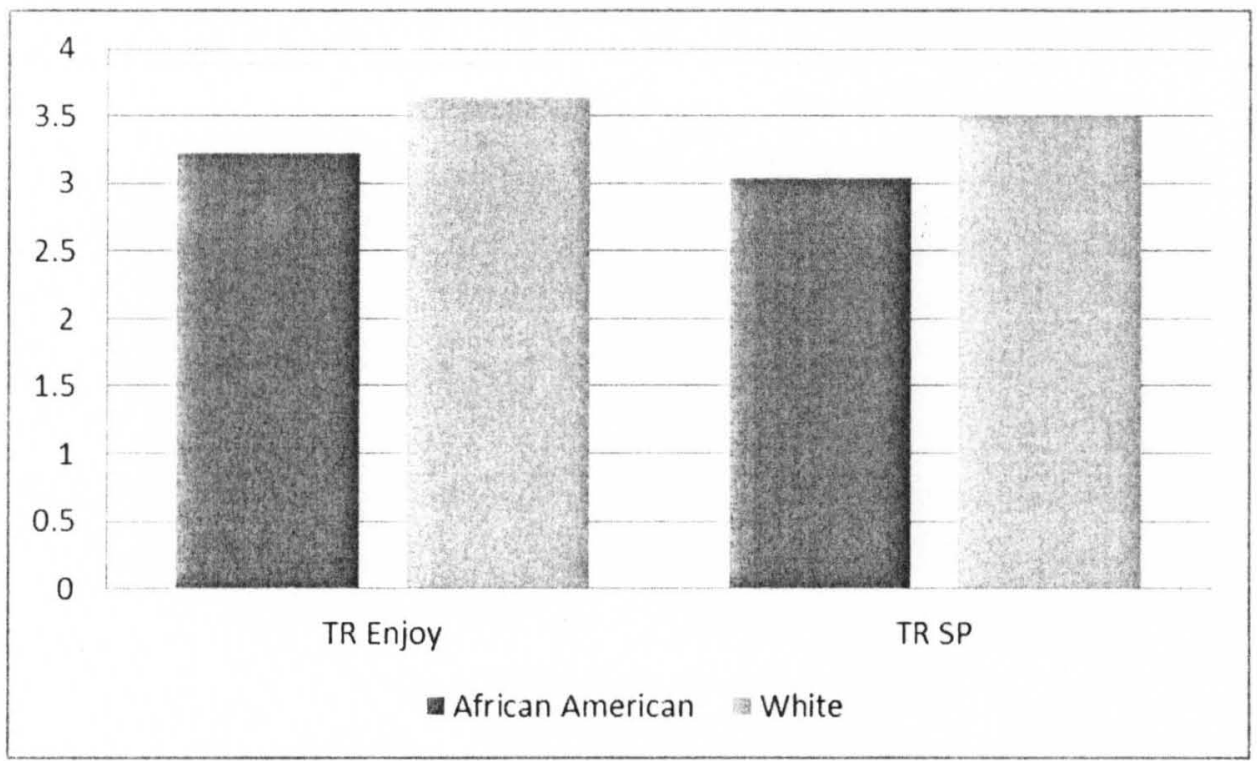

Figure 3. Comparisons of White and African American students on Teacher Ratinngs of Mathematics Enjoyment and Mathematics Self-perceptions.

How do teacher ratings of African American students' mathematics ability, enjoyment, and self-perceptions correlate with student ratings of their own mathematics enjoyment and self-perceptions? How do these correlations compare to the same correlations for White students?

Correlations were conducted between teachers' ratings of student enjoyment of mathematics and mathematics self-perceptions and students' self-reports of the same constructs. Overall, correlations for both ethnicities on both constructs were statistically significant. As shown in Tables 5 and 6, correlations between teachers' ratings of enjoyment and students' self-report ratings of enjoyment and teachers' ratings of student self- perceptions and students' self-report ratings of self-perceptions were higher for White students $\left(r_{\text {enjoyment }}=.321\right.$ and $\left.r_{\text {self-perceptions }}=.405\right)$ than African American students $\left(r_{\text {enjoyment }}=.261\right.$ and $\left.r_{\text {selfperceptions }}=.325\right)$. 
Table 5

Correlations of Student and Teacher Variables for African American Students

TR student TR student self

enjoyment

perception

Student enjoyment

$.261^{* *}$

$---$

Student self perceptions

$.325 * *$

$* * p<.01$

Table 6

Correlations of Student and Teacher Variables for White Students

\begin{tabular}{ccc}
\hline & $\begin{array}{c}\text { TR student } \\
\text { enjoyment }\end{array}$ & $\begin{array}{c}\text { TR student self } \\
\text { perception }\end{array}$ \\
\hline $\begin{array}{c}\text { Student enjoyment } \\
\text { Student self perceptions }\end{array}$ & $.321^{* *}$ & --- \\
\hline
\end{tabular}

$* * p<.01$

Do differences exist between teacher-rated attitudes and student-rated

attitudes? If differences do exist, are they the same for African American and

White American students?

To better assess ethnic differences in how teachers rate students compared to how students rate themselves, a difference score was created for both mathematics self-

perceptions and enjoyment, and ANOVAS were computed to examine group differences based on ethnicity.

The Levene's Test for both the Enjoyment Difference Score, $F(1,1362)=.277, n s$, and the Self-Perceptions Difference Score, $F(1,1376)=.681, n s$, were not statistically significant, indicating that group variances for the sample were equal (i.e., not violating the assumption of homogeneity of variance). As shown in table 7 , statistically significant differences between ethnic groups were found for both the mathematics self-perceptions, $F(1,1376)=47.76, p<.01, \omega=.185$, and enjoyment, $F(1,1362)=60.38, p<.01, \omega=$ 
.208, difference scores. Teachers overrated White students $\left(M_{\text {selfperceptionsdiff }}=-.195\right.$, $\left.M_{\text {enjoymentiff }}=.102\right)$, while underrating African American students $\left(M_{\text {selfperceptionsdiff }}=\right.$ -

$\left..722, M_{\text {enjoymentdiff }}=-.586\right)$ on average. Effect sizes for both the mathematics enjoyment and self-perceptions difference scores represented relatively large effects (Field, 2009).

Figure 4 shows differences between White students and African American students in their difference scores for enjoyment and self-perceptions.

Table 7

Summary of ANOVA for Mathematics Self-Perceptions and Enjoyment Difference Score

\begin{tabular}{|c|c|c|c|c|c|c|c|}
\hline & & $\begin{array}{l}\text { Sum of } \\
\text { squares }\end{array}$ & $d f$ & $\begin{array}{c}\text { Mean } \\
\text { square }\end{array}$ & $F$ & $p$ & $\Omega$ \\
\hline \multirow[t]{2}{*}{$\begin{array}{l}\text { Self-Perceptions } \\
\text { Diff }\end{array}$} & Between Groups & 48.05 & 1 & 48.05 & $47.76^{* *}$ & .000 & .185 \\
\hline & $\begin{array}{l}\text { Within Groups } \\
\text { Total }\end{array}$ & $\begin{array}{l}1384.28 \\
1432.33\end{array}$ & $\begin{array}{l}1376 \\
1377\end{array}$ & 1.01 & & & \\
\hline Enjoyment Diff & $\begin{array}{l}\text { Between Groups } \\
\text { Within Groups } \\
\text { Total }\end{array}$ & $\begin{array}{r}80.80 \\
1822.60 \\
1903.40\end{array}$ & $\begin{array}{r}1 \\
1362 \\
1363\end{array}$ & $\begin{array}{r}80.80 \\
1.34\end{array}$ & $60.38^{* *}$ & .000 & .208 \\
\hline
\end{tabular}

$* * \mathrm{p}<.01$ 


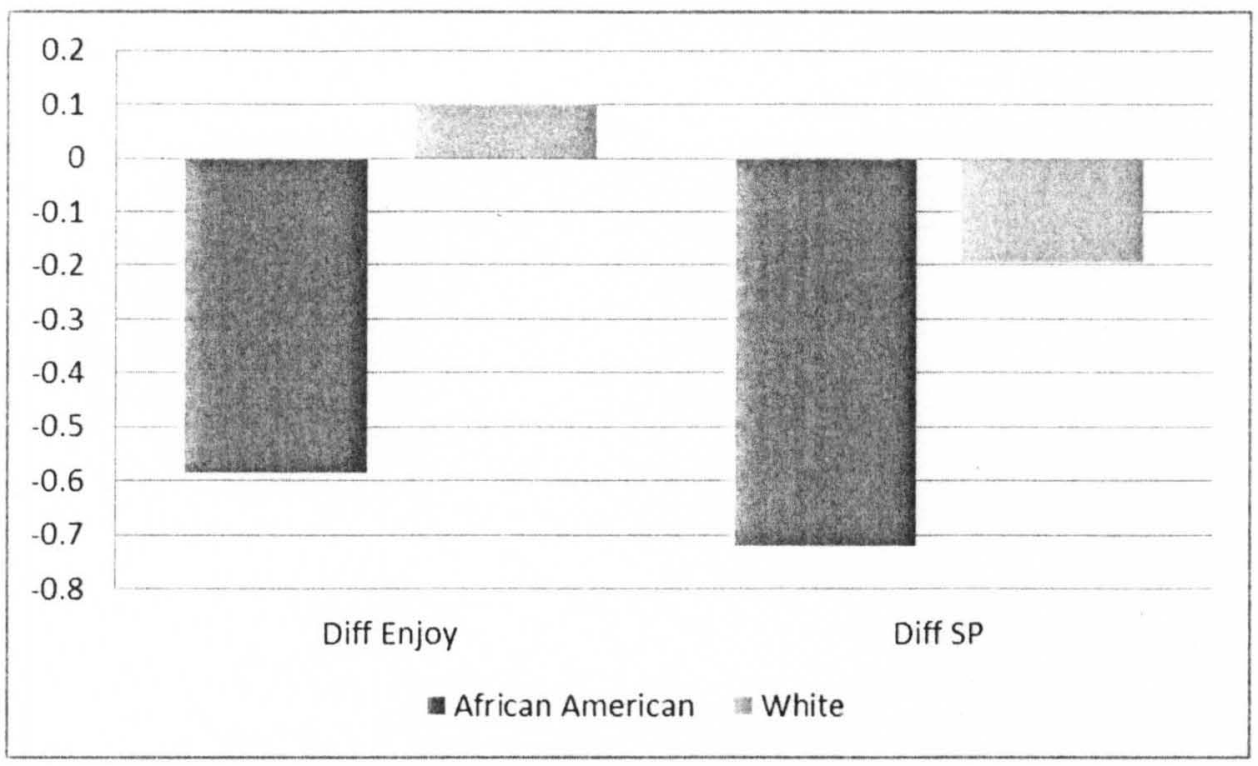

Figure 4. Comparisons of mean differences between teacher and student ratings for Mathematics Enjoyment and Mathematics Self-Perceptions for African American and White Students

\section{Summary of Findings}

In conclusion, the current study found that African American students in this sample enjoyed mathematics significantly more than White students and perceived themselves in mathematics at the same level. I also found through comparing teacher ratings across ethnicity and through comparing difference scores across ethnicity that teachers had a tendency to underrate African American students while overrating White students. These differences in ratings were found to be statistically significant. The next chapter will discuss these results in detail and will provide implications for future research. 


\section{CHAPTER FIVE \\ SUMMARY AND DISCUSSION}

\section{Summary of Thesis}

The widening achievement gap between African American students and students of other ethnicities remains a reality and yet a mystery to solve nationwide. The alarming results of previous literature on the underachievement of African American students provide more reason as to why research in this area is important, and it propels researchers to search for answers to the mystery. African American students' attitudes and beliefs about their academic experiences often do not match the perceptions of their teachers (Garibaldi, 1992). Stereotypes about African American students as a whole may lead teachers to apply generalized expectations to these students (Ferguson, 2003). Teachers may perceive these students' academic ability, attitudes, and motivation negatively even though African American students may experience this positively. Unfortunately, negative teacher expectations may lead to experiences such as selffulfilling prophecies. Teachers who hold negative perceptions of African American students could potentially negatively affect students who have high abilities, positive selfperceptions and self-concepts, and high expectations (Ferguson, 2003; Garibaldi, 1992).

There are two theoretical perspectives bearing on the academic successes of African American students. Historically, researchers have focused on the ways in which negative stereotypes regarding academics have had negative impacts on the academic 
achievement of African American students. However, recent researchers have moved focus to understanding concepts surrounding African American students who have been successful in their academic pursuits regardless of the negative environmental and social factors that stereotype theory addresses. Research on understanding educational attitudes as a whole can be used as a foundation to understanding academic resiliency. Some researchers contend that facilitation of resiliency can be used as a way to close the educational gap that exists for African American students (Cook \& Ludwig, 1998; Fryer \& Torelli, 2005; Tyson, 2002).

\section{Discussion}

The results of this study first found evidence suggesting the potential for negative stereotypes being displayed by teachers. In looking at how teachers rated students, this study not only found that teachers rated White students significantly higher than African American students on average for both mathematics enjoyment and mathematics selfperceptions but also that they significantly underrated African American students while significantly overrating White students on these measures. In addition to this, correlations between teachers' ratings and student reports for both enjoyment and self-perceptions were lower for African American students than for their White counterparts. These findings suggest that teachers in the current study possibly hold certain stereotypes and possibly racist views about African American students that led them to believe these students do not enjoy or perceive themselves highly in the subject they teach. Not only do these results reflect possible negative stereotypes about African American students, but they also may reflect positive stereotypes about White students, that White students will enjoy mathematics and perceive themselves better in a subject in which they may not. 
Considered in light of stereotypes suggesting that African American students do not perform as well academically and do not enjoy courses such as mathematics (Ferguson, 2003; Gerabaldi, 1992), these results indicate that for some African American students there is some force that prevents the deterioration of their enjoyment and selfperceptions in performing well in certain subjects. The current study agrees with findings in similar studies of African American children and youth in which these students enjoy subjects and activities that they stereotypically should not. Regardless of negative stereotypes and expectations about their ethnic group they have positive experiences with these situations (Cook \& Ludwig, 1998; Fryer \& Torelli, 2005; Gutman, 2006; Gutman \& Midgley, 2000; Tyson, 2002).

Wilson and Corbett (2001) and Tyson (2002) found that negative attitudes were not as prevalent among African American students as previous research purports. The African American students in this sample reflected this, expressing enjoyment of mathematics more than their White counterparts, supporting those findings. Likewise, where stereotype theorists would expect African American students to perceive themselves in mathematics lower than White students, there were no significant differences between African American students and White students in their mathematics self-perceptions.

African American students not only reported greater enjoyment of mathematics and equally high self-perceptions in mathematics compared to White students, but teachers' ratings seemed to reflect a complete opposite effect, undermining the strength of these African American students. Though teachers seemed to underrate African American students overall compared to White students, teacher-to-student correlations 
revealed that teachers in the current study seemed to do a poor job at perceiving students' mathematics enjoyment and self-perceptions as a whole. This poor perception was for White students as well; however, it was even worse for African American students.

Because the African American students in this sample enjoyed mathematics and perceived themselves positively in mathematics regardless of their teachers' underrated and lowered expectations, these findings deny the concept of threat of stereotypes for African American students in this sample, and therefore support resiliency theory. Because this study was not developed to place students in a specific stereotype threat situation and examine their performance like the theory holds, only partial connections and interpretations can be made. However, in reexamining the conceptual framework of Stereotype Threat Theory, some conceptual associations can be made with how stereotypes and possible racism may have not been perceived by students in the current study. The framework states that African American students who are invested in their mathematics test performance will be susceptible to stereotype threat in a high stereotype-threat situation. In the current study, African American students presented being invested in mathematics by reflection of their enjoyment and positive selfperceptions concerning the subject. Teacher's underrating African American students in the current study reflects a generation of possible stereotype threat because if these low expectations or stereotypes are perceived and internalized, they can have negative impacts on students. In the conceptual model, concerns about fulfilling a negative stereotype (i.e. "Blacks do not do well in math") may then bring about a performanceavoidance goal orientation. Our study suggests the possibility that young African American students at the elementary level may not have developed the ability to perceive 
negative stereotypes and therefore may not actively think or worry about fulfilling these stereotypes. In the model, a performance-avoidance goal may then lead to an increase in worry and test anxiety, make self-efficacy vulnerable, which may lead to negative educational experiences (Ryan \& Ryan, 2005).

However, the current study suggests that there may be certain factors that intervene with this process and foster things such as an increased self-perceptions regardless of these negative stereotypes so that African America students are still able to have these positive attitudes and outcomes and enjoy subjects such as mathematics. To make specific connections to Stereotype Threat theory, ability tasks and measures would be needed in order to assess the effects (or lack of effects) of the stereotypes possibly displayed by teachers to African American students in the current study. However, the scope of this study specifically focused on student mathematics enjoyment and selfperceptions; therefore, recommendations for future research involve including an ability variable.

Nonetheless, per the conceptual framework of this study, the interpretations of these results support resiliency theory showing that African American children at a young age can be surrounded by negative expectations due to the social construction of our society and yet be resilient in their enjoyment and self-perceptions in certain academic areas. According to these results, African American students enjoyed and perceived themselves in mathematics at higher rates than White students regardless of their teachers' low perceptions of them. These results may indicate that at a young age there are buffers that aid resiliency in African American that could have positive effects on their academic experiences. Furthermore, if what Whitin (2007), Dumais (2009), and 
Skaalvik and Skaalvik (2006) expressed about the positive effects of educational attitudes and beliefs on ability is true, this may predispose these students to possible educational success. Nonetheless, these results may suggest that African American students at this age have not yet developed the ability to recognize and/or internalize stereotypes and are not yet aware of racism associated with their ethnic group. This may be a reflection of the process and stages of racial ethnic identity as well as life and psychosocial development. Therefore, as explained in the following section, future research should seek to find ways to better assess these factors in association with stereotype perceptions and resiliency.

\section{Implications for Further Research}

Due to the dearth of literature in this area pertaining to African American students, future research is needed to make stronger empirical implications of results. The findings from the current study may bode useful for future research by providing researchers with more reason to examine these phenomena more closely.

Teachers in the current study underrated African American students. Does this reflect stereotypes that teachers, specifically White teachers, may have about African American students, and if so how does this affect the way in which these teachers engage these students? Literature contends that teachers play such an important role in the attitudes and achievement of students (Love, 2001). Do teachers who stereotypically do not believe students of certain ethnic groups enjoy their subject act or teach differently to these students, and at what point will these students internalize these low expectations? It would be beneficial for future research to explore how teachers may present a selffulfilling prophecy specifically pertaining to racial and ethnic stereotypes in their perceptions of student beliefs and attitudes. 
Literature points to the ability for African American students to be resilient, and the current study found these results focusing specifically on students in grades 3 through 6. It would be useful to assess if the same results would be found in lower grades and at the middle school, high school, and collegiate level. In the current study African American students at the young age reflected an academic resiliency that propelled their enjoyment in areas that are stereotypically not enjoyed by their ethnic group, but this brings about questions surrounding the age level at which these students begin to internalize negative stereotypes. There may possibly be a point during middle school in which African American students who previously enjoyed and perceived themselves well in mathematics or other academic areas begin to pick up on the expectations and stereotypes of teachers and their surrounding environment. There seems to be a battle in this research field between stereotype theory and resiliency theory; however, future research may find a relationship between the two. As described, resiliency theory may hold true for younger children who are less socialized and less aware of the stereotypes that surround their ethnic group, yet at some age, a development of this awareness may occur in which stereotypes are internalized. At this point without certain buffers like those mentioned in previous literature, such as parental and teacher support and positive expectations, academic and environmental resources, positive teacher interactions and parental style, stereotype theory may then take precedence (Griffin \& Allen, 2006; Love, 2001; Midgley et al., 1989; Mitchell, 2002; Nettles et al., 2000). Researchers can find ways to assess when this occurs and what factors enable resiliency to continue regardless of it. 
This study's findings also suggest support for resiliency theory, finding that African American students enjoy and have high self-perceptions in mathematics regardless of low expectations and stereotypes of their teachers. It would be beneficial for future research to find better ways to measure resiliency among students and stereotyping among teachers. Getting students' perceptions of stereotypes about their ethnic group and their opinions of their teachers' perceptions and stereotypes as well as exploring teachers' stereotypes specifically would aid in this. In addition to this, though the current study had an overwhelming sample of White teachers, comparisons between White teachers and African American teachers would be useful in seeing if these stereotypes are presented within ethnic groups also.

Nonetheless, in examining resiliency, it is not only important to look at student attitudes in relation to teacher expectations, but also to look at student achievement and ability outcomes. As mentioned throughout this thesis, positive correlations have been discovered between educational attitudes and achievement, and we can conceptually assume those same correlations can be made with regards to resilient attitudes and achievement for African American students. However, future research is needed in making empirical connections between resiliency and achievement of African American students in order to assess exactly how these students are resilient and to get a better picture of what resiliency looks like in these students academically.

The current study also only focused on students in three counties in the same state, and it presented a low number of African American students compared to White students. Exploration of other demographic areas would strengthen implications of the theories researched in this study and would allow for broader application. It would also 
allow us to see similarities and/or differences between varying regions. With a larger African American sample, we may see larger differences and stronger effects for the factors examined.

Because it only examined African American and White students, the current study limited itself in its cross-racial comparisons. Future research on comparisons among the same factors examined in this study but across other ethnic groups is necessary. This research would allow us to discover if other ethnic minorities are affected by stereotypes or if they present a resiliency like that of the African American students in the current study. It would also allow researchers to examine if teachers perceptions and expectations vary across different ethnic groups.

\section{Implications for Practical Application}

This study is limited in predictive power; however, the results of this study have implications for a wide range of individuals including parents, teachers, school and district personnel, school counselors, academic institutions that prepare teachers, and community leaders. The basis of stereotype threat theory emphasizes the way in which several systems in an African American student's life can have negative effects on that student. However, resiliency theory emphasizes how these same systems can be used in the opposite manner, through the help of parents, teachers, and other important individuals in order to have positive impacts on these student's academic experiences. This study highlights the importance of individuals working with African American students and families to take on a multi-systemic view in trying to understand their experiences. 
Several systems (e.g. home and school environment, parental and family attributes, teacher characteristics, classroom learning environment, social and societal factors.), play such an important role in the success or failure of these students. Research has found significant connections between school resources and student outcomes including academic performance, educational attitudes, and access to higher education. One study showed that schools with more resources were found to place a greater emphasis on college and produced more graduates who were college bound than schools with fewer resources (Griffin \& Allen, 2006). In addition to this, the importance and effects of parental action and support in the lives of resilient students has also been explored. Research has found that high expectations and high parental involvement in the academic lives of at-risk students can prove to be very valuable (Nettles et al., 2000). Moreover, there are factors associated with parenting styles and child rearing practices that can positively affect academic experiences of young children. Parents of highachieving and highly academically motivated elementary-age students have a tendency to use different parenting strategies than those of low-achieving students. These parenting strategies, such as increased parental support, can lead to students having more positive educational outcomes which can help foster stronger resiliency among these students. High expectations and high parental involvement can be very valuable to fostering the academic resiliency of African American students (Dass-Brailsford, 2005; Nettles et al., 2000). It is also equally important for parents and leaders within the African American community to understand the effects of stereotypes and make efforts to facilitate resiliency among African American children and youth that will withstand negative forces within their home and school environment. 
Another area for facilitating resiliency with these students includes increasing academic and school resources. Schools with more resources and higher affluence have been associated with better performance and higher motivation to pursue higher education among African American students (Griffin \& Allen, 2006; Lee et al., 1991).

Lastly, research such as that examined in the current study makes it imperative for teachers to understand systems that may affect African American students including societal stereotypes, racism, and resiliency. It is important that teachers recognize stereotypes they may possess with regards to certain ethnic minority populations. Results from this study can be used to make teachers and principals aware not only of their own biases towards certain groups but also of their perceptions of students in general. Furthermore, recognizing these perceptions and expectations is not enough; rather,understanding the effects that these factors can have on students is even more important. This requires the implementation and emphasis of positive teacher support and student-teacher relationships. As continuously expressed, teachers play an important role in the academic self-perceptions of students, and those self-perceptions fosters better academic performance and higher educational attainment of African American students (Dass-Brailsford, 2005; Love, 2002). 


\section{REFERENCES}

Adelson, J. L. (2006). Math and Me. Unpublished instrument.

Adelson, J. L., \& McCoach, D. B. (In press). Development and psychometric properties of the Math and Me Survey: Measuring third through sixth graders' attitudes towards mathematics. Measurement and Evaluation in Counseling and Development.

Allen, B. A., \& Boykin, A. W. (1992). African American children and the educational process: Alleviating cultural discontinuity through prescriptive pedagogy. School Psychology Review, 21, 586-596.

Au, K., \& Jordan, C. (1981). Teaching reading to Hawaiian children: Finding culturally appropriate solutions. In H. Trueba, G. Guthrie, and K. Au (Eds.), Culture and the Bilingual Classroom: Studies in Classroom Ethnography (pp. 139-152), Rowley, MA: Newbury.

Beane, J. \& Lipka, R. (1987). Self-concept, self-esteem, and the curriculum. Boston: Allyn \& Bacon.

Bell, D. (1987). And we are not saved: The elusive quest for racial justice. New York: Basic Books. 
Bernal, D. (2002). Critical race theory, Latino critical theory, and critical raced-gendered epistemologies: Recognizing students of color as holders and creators of knowledge. Qualitative Inquiry, 8, 105-126.

Bloom, A. (2008, December 5). Attitudes to math fixed by age 9. Times Educational Supplement. Retrieved from http://www.tes.co.uk/publications.aspx?navcode=91

Brier, N. (1995). Predicting anti-social behavior in youngsters displaying poor academic achievement: A review of risk factors. Journal of Developmental and Behavioral Pediatrics, 16, 271-276.

Cazden, C. B. \& Leggett, E. (1981). Culturally responsive education: Recommendations for achieving Lau remedies II. In H. Trueba, G. Guthrie, \& K. Au (Eds.), Culture and the Bilingual Classroom: Studies in Classroom Ethnography (pp. 69-86), Rowley, MA: Newbury.

Cook, P. J. \& Ludwig, J. (1998). The burden of "acting White": Do Black adolescents disparage academic achievement? In C. Jenkins \& M. Phillips (Eds.), The BlackWhite test score gap (pp. 375-400). Washington, DC: Brookings Institution Press. Crenshaw, K., Gotanda, N., Peller, G., \& Thomas, K. (1995). Critical race theory: The key writings that formed the movement. New York: The New Press.

Dass-Brailsford, P. (2005). Exploring resiliency: Academic achievement among disadvantaged black youth in South Africa. South African Journal of Psychology. Suid-Afrikaanse Tydskrif Vir Sielkunde, 35, 574-591.

Delgado, R. \& Stefancic, J. (2001). Critical race theory: An introduction. New York: New York University Press. 
Dumais, S. A. (2009). The academic attitudes of American teenagers. Social Science Research, 38, 767-780. doi: 10.1016/j.ssresearch.2009.05.010

Eccles, J. S., Jacobs, J. E., \& Harold, R. D. (1990). Gender-role stereotypes, expectancy effects, and parents' role in the socialization of gender differences in selfperceptions and skill acquisition. Journal of Social Issues, 46, 183-201.

Edwards, P. A. \& McMillion, G. T. (2000). Why does Joshua "hate" school...but love Sunday school? Language Arts, 78, 111-120.

Ferguson, R. F. (2003). Teachers' perceptions and expectations and the Black-White test score gap. Urban Education, 38, 460-507.

Field, A. (2009). Discovering statistics using SPSS. Thousand Oaks, CA: SAGE Publications, Inc.

Fordham, S., \& Ogbu, J. S. (1986). Black students' school success: Coping with the burden of "acting White". The Urban Review, 18, 176-206.

Fraser, B. J. \& Fisher, D. L. (1982). Predicting students' outcomes from their perceptions of classroom psychosocial environment. American Educational Research Journal, 19, 498-518.

Fryer, R. G. \& Torelli, P. (2005). An empirical analysis of "acting White” (Working Paper No. 11334). Cambridge, MA: National Bureau of Economic Research.

Garibaldi, A. M. (1992). Educating and motivating African American males to succeed. Journal of Negro Education, 61, 4-11.

Griffith, J. (1996). Relation of parental involvement, empowerment, and school traits to student academic performance. Journal of Educational Research, 90, 33-41. 
Griffin, K.A. \& Allen, W.R. (2006). Mo? money, mo? problems?: High achieving Black high school students? Experiences with resources, racial climate, and resilience. Journal of Negro Education, 75, 478-494.

Gutman, L. M. (2006). How student and parent goal orientations and classroom goal structures influence the math achievement of African Americans during high school transition. Contemporary Educational Psychology, 31, 44-63. doi: 10.1016/j.cedpsych.2005.01.004

Gutman, L. M. \& McLoyd, V. C. (2000). Parents management of their children's education within the home, at-school, and the community: An examination of African American families living in poverty. The Urban Review, 32, 1-24.

Hale-Benson, I. E. (1986), Black children: Their roots, culture, and learning styles. Baltimore: John Hopkins University Press.

Hartmut, J. (1978). Supportive dimensions of teacher behavior in relationship to pupil emotional cognitive processes. Psychology in Erziehung and Unterricht, 25, 6974.

Heubert, J.P. \& Hauser, R.M. (1999). High Stakes: Testing for Tracking Promotion and Graduation. Washington, D.C.: National Academy Press.

Howard, T. C. (2001). Telling their side of the story: African-american students' perceptions of culturally relevant teaching. Urban Review, 33, 131-150.

Inzlicht, M. \& Ben-Zeev, T. 2000. A threatening intellectual environment: Why females are susceptible to experiencing problem-solving deficits in the presence of males. Psychological Science, 11, 365-71. 
Jencks, C. \& Phillips, M. (1998). The Black-White test score gap. Washington, D. C.: Brookings Institution Press.

Jones, S. (1973). Self and interpersonal evaluations: Esteem versus consistency theories. Psychological Bulletin, 79, 185-199.

Justice, E. M., Lindsey, L. L. \& Morrow, S. F. (1999). The relation of self-perceptions to achievement among African American preschoolers. Journal of Black Psychology, 25, 48-60.

Ladson-Billings, G. \& Tate, W. (1995). Toward critical race theory of education. Teachers College Record, 97, 47-64.

Laird, J., Lew, S., DeBell, M. \& Chapman, C. (2006). Dropout rates in the United States: 2002 and 2003 (NCES 2006-062). U.S. Department of Education. Washington, DC: National Center for Education Statistics.

Lalley, J. P. \& Miller, R. H. (2006). Effects of pre-teaching on math achievement and academic self-concept of students with low achievement in math. Education, 126, 747-755.

Lazarowitz, C. Webb, \& R. Schmuck (Eds.). (1985). Learning to cooperate, cooperating to learn. New York: Plenum.

Lecky, P. (1945). Self consistency: A theory of personality. New York: Island Press.

Lee, V. E., Winfield, L. F., \& Wilson, T. C. (1991). Academic behaviors among highachieving African-American students. Education and Urban Society, 48, 65-86.

Lewis, C. (1995). Educating hearts and minds: Reflections on Japanese preschool and elementary education. New York: Cambridge University Press. 
Lewis, J. L. \& Kim, E. (2008). A desire to learn: African American children's positive attitudes toward learning within school cultures of low expectations. Teachers College Record, 110, 1304-1329.

Love, A. (2002). Teachers' beliefs and their relationship to student achievement in two African American urban schools. Dissertation Abstracts International: Section A. Humanities and Social Sciences, 62(10), 3293.

Lynn, M., Yosso, T., Solorzano, D., \& Parker, L. (2002). Critical race theory and education: Qualitative research in the new millennium. Qualitative Inquiry, 8, 3-6.

Marsh, H. W. (1984). Relations among dimensions of self-attribution, dimensions of selfattribution, dimensions of self-concept, and academic achievements. Journal of Educational Psychology, 76, 63-78.

Marsh, H. W., Byrne, B. M., \& Shavelson, R. J. (1988). A multifaceted academic selfconcept: Its hierarchical structure and its relation to academic achievement. Journal of Educational Psychology, 80, 366-380.

Marsh, H. W., \& Yeung, A. S. (1997). Casual effects of academic self-concept on academic achievement: Structural equation models of longitudinal data. Journal of Educational Psychology, 89, 41-54.

Midgley, C., Feldlaufer, H., \& Eccles, J. (1989). Student/teacher relations and attitudes toward mathematics before and after the transition to junior high school. Child Development, 60, 981-993. doi: 10.1111/1467-8624.ep9676559

Midgley, C., Feldlaufer, H., \& Eccles, J. S. (2000). Change in teacher efficacy and student self- and task-related beliefs in mathematics during the transition to junior high school. Journal of Educational Psychology. 81, 247-258. 
Mitchell, Y. (2002). Child-rearing styles and achievement test performance of AfricanAmerican students: An individual growth analysis. Dissertation Abstracts International: Section A. Humanities and Social Sciences, 63(3), 914.

Moos, R. H. (1979). Evaluating educational environments. San Francisco: Jossey-Bass.

Morales, E. E., \& Trotman, F. K. (2004). Promoting academic resilience in multicultural America: Factors affecting student success. New York: Peter Lang Publishing.

National Center for Education Statistics [NCES] (2001). NAEP summary tables [online]. Washington, DC: US Department of Education. Retrieved from http://nces.ed.gov/nationsreportcard

National Center for Education Statistics [NCES] (2009). Achievement gaps: How Black and White students in public schools perform in mathematics and reading on the National Assessment of Educational Progress (NCES Publication No. 2009-455). Retrieved from http://eric.ed.gov/PDFS/ED505903.pdf

National Postsecondary Education Cooperative, Gandara, P., Bial, D., \& National Center for Education Statistics (2001). Paving the way to postsecondary education: K-12 intervention programs for underrepresented youth. Retrieved from http://nces.ed.gov/pubs2001/2001205.pdf

Nettles, S. M., Mucherah, W., \& Jones, D. (April 01, 2000). Understanding Resilience: The role of social resources. Journal of Education for Students Placed at Risk, 5, $47-60$.

O'Connor, C. (1997). Dispositions toward (collective) struggle and educational resilience in the inner city: A case analysis of six African-American high school students. American Educational Research Journal, 34, 593-629. 
Ogbu, J. (2003). Black Students in an Affluent Suburb: A Study of Academic

\section{Disengagement.}

Hillsdale, NJ: Lawrence Erlbaum.

Pastorelli, C., Caprara, G. V., Barbaranelli, C., Rola, J., Rozsa, S., \& Bandura, A. (2001). The structure of children's perceived self-efficacy: A cross-national study. European Journal of Psychological Assessment, 17, 87-97.

Roach, R. (1999). Succeeding on white campuses. Black Issues in Higher Education, $15,42-43$.

Ryan, K. E., \& Ryan, A. M. (2005). Psychological processes underlying stereotype threat and standardized math test performance. Educational Psychologist, 40, 53-63.

Sadker, M. \& Sadker, D. (1986). Sexism in the classroom: From grade school to graduate school. Phi Delta Kappan, 67, 512-515.

Schmidt, W. (March 01, 2003). Too little too late: American high schools in an international context. Brookings Papers on Education Policy, 1, 253-308.

Shavelson, R. J. \& Bolus, R. (1982). Self-concept: The interplay of theory and methods. Journal of Educational Psychology, 74, 3-17.

Signer, B., Beasley, M., \& Bauer, E. (1996, April). A study of the interaction of ethnicity, math achievement, socioeconomic status, and gender on math attitudes of high school students. Paper presented at the meeting of National Science Foundation American Educational Research Association, New York City, NY.

Skaalvik, E. M. \& Hagtvet, K. A. (1990). Academic achievement and self-concept: An analysis of casual predominance in a developmental perspective. Journal of Personality and Social Psychology, 9, 211-220. 
Skaalvik, E. M. \& Skaalvik, S. (2006). Self-concept and self-efficacy in mathematics: Relation with mathematics motivation and achievement. Proceedings of the International Conference on Learning Sciences, Bloomington, IN. Retrieved from http://www.findarticles.com

Spencer, S. J., Steele, C. M., \& Quinn, D. M. (1999). Stereotype threat and women's math performance. Journal of Experiential Social Psychology, 35, 4-28.

Steele, C. M. (1998). Stereotyping and its threat are real. American Psychologist, 53, 680681.

Steele, C. M., \& Aronson, J. (1995). Stereotype threat and the intellectual test performance of African Americans. Journal of Personality and Social Psychology, 69, 797-811.

Tapia, M. (1996, November). The Attitudes Toward Mathematics Inventory. Paper presented at the Annual Meeting of the Mid-South Educational Research Association, Tuscaloosa, AL.

Tate, W. (1997). Critical race theory and education: History, theory, and implications. Review of Research in Education, 22, 195-247.

Thomas, D. R. \& Zumbo, B. D. (2011). Difference scores from the point of view of reliability and repeated-measure ANOVA: In defense of difference scores for data analysis. Educational and Psychology Measurement, 20, 1-7.

Thorndike-Christ, T. (1991). Attitudes toward mathematics: Relationships in mathematics achievement, gender, mathematics course-taking plans, and career interests. Washington: Western Washington University. (ERIC Document Reproduction Service No. ED3470466) 
Trickett, E. J. \& Moos, R. H. (1974). Personal correlates of contrasting environments: Student satisfactions in high school classrooms. American Journal of Community Psychology, 2, 1-12.

Tyson, K. (2002). Weighing in: Elementary-age students and the debate on attitudes toward school among black students. Social Forces, 80, 1157-1190.

Vaught, S., \& Castagno, A. (2008). "I Don't Think I'm a Racist:" Critical Race Theory, Teacher Attitudes, and Structural Racism. Race, Ethnicity and Education, 11, 95113.

Wang, M. C., Haertel, G. D., Walberg, H. J., \& Educational Resources Information Center (U.S.). (1995). Research on school effects in urban schools. Philadelphia, PA: National Center on Education in the Inner Cities.

Watson, M. B. \& Stead, G. B. (1997). Black South-African adolescents' attitudes about studying. Psychological Reports, 80(1), 861-863.

West, C. K., Fish, J. A., \& Stevens, R. J. (1980). General self-concept, self-concept of academic ability, and school achievement: Implications for "causes" of selfconcept. Australian .Journal of Education, 24, 194-213.

Whitlin, P. E. (2007). The mathematics survey: A tool for assessing attitudes and dispositions. Teaching Children Mathematics, 13, 426-432.

Wigfield, A., Eccles, J. S., \& Pintrich, P. R. (1996). Development between the ages of 11 and 25. In D. C. Berliner and R. C. Calfee (Eds.), Handbook of Educational Psychology (pp. 148-185). New York: Prentice Hall International. 
Wigfield, A. \& Karpathian, M. (1991). Who am I and what can I do? Children's selfconcepts and motivation in academic situations. Educational Psychologist, 26, 233-262.

Wilson, B. L. \& Corbett, H. D. (2001). Listening to urban kids: School reform and the teachers they want. Albany: State University of New York Press.

Wilson-Jones, L. \& Caston, M. C. (2004). Cooperative learning on academic achievement in elementary African American males. Journal of Instructional Psychology, 31, 280-283 
APPENDIX A

This page will not be with your survey.

Your teacher will not see your survey, and the researchers will not see your name.

Survey number:

First name:

Last name: 


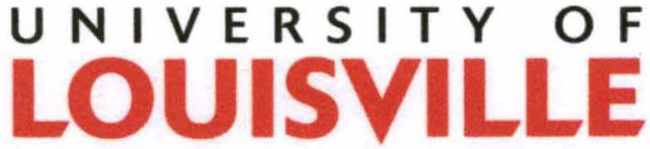 It's Happening Here.}

Dear Student,

We would like you to help us with our work at the University of Louisville. We want to learn more about how students feel about math. This will help teachers. We are testing out a survey called the Math and Me Survey. It will only take about 5 to 10 minutes to complete. To help us learn about how students feel about and learn math, we also will ask your teacher how she or he thinks you feel about math, and we will collect your math scores. This study is anonymous. That means that we will NOT have your name with the information. Your name will not be on the survey. We will use the survey code to collect math scores. The survey is confidential. That means NO ONE besides the researchers (not even your teacher) will see your survey. We really hope you will help us. This would be your choice. It would not be a part of your grade. If you want to participate, please complete the attached survey. If you do not want to help, leave it blank. Please let us know if you have any questions!!

Sincerely,

Dr. Jill Adelson

Assistant Professor

University of Louisville 


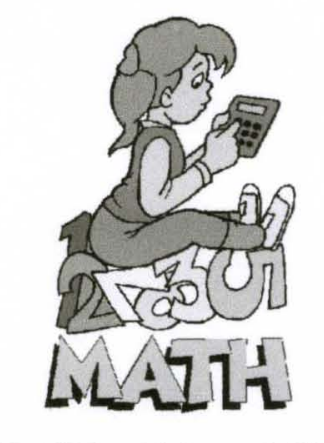

() Jill L. Adelson, 2006

\section{and Me Survey}

Please circle $\underline{O N E}$ response for each question. Be sure to answer $\underline{A L L}$ the questions. Remember that there are no "right" or "wrong" answers. These are about how you feel about math. Please do not write your name on this survey.

SD = strongly disagree disagree
$D=$ disagree
$\mathrm{N}=$ neither agree nor

$$
A=\text { agree } S A=\text { strongly agree }
$$

\begin{tabular}{|l|lllll|}
\hline \multicolumn{1}{|c|}{ Statement } & How I Feel & & \\
\hline 1. I am really good at math. & $S D$ & $D$ & $N$ & $A$ & $S A$ \\
2. I love math. & $S D$ & $D$ & $N$ & $A$ & $S A$ \\
3. I understand math. & $S D$ & $D$ & $N$ & $A$ & $S A$ \\
4. Math is boring. & $S D$ & $D$ & $N$ & $A$ & $S A$ \\
5. I can solve difficult math problems. & $S D$ & $D$ & $N$ & $A$ & $S A$ \\
6. I enjoy doing math puzzles. & $S D$ & $D$ & $N$ & $A$ & $S A$ \\
7. Math is very hard for me. & $S D$ & $D$ & $N$ & $A$ & $S A$ \\
8. I do math problems on my own "just for fun." SD & $D$ & $N$ & $A$ & $S A$ \\
9. Math is confusing to me. & $S D$ & $D$ & $N$ & $A$ & $S A$ \\
10. Math is fun. & $S D$ & $D$ & $N$ & $A$ & $S A$ \\
\end{tabular}


11. I look forward to learning new math.

12. Math comes easily to me.

\begin{tabular}{|c|c|c|c|}
\hline SD & $D$ & $\mathbf{N}$ & $A$ \\
\hline & $D$ & $\mathbf{N}$ & $A$ \\
\hline
\end{tabular}


SD = strongly disagree $\quad D=$ disagree $\quad N=$ neither agree nor disagree

$$
\begin{aligned}
& A=\text { agree } \quad S=\text { strongly } \\
& \text { agree }
\end{aligned}
$$

\begin{tabular}{|c|c|c|c|c|}
\hline Statement & Hon & Fee & & \\
\hline 13. I hate math. & SD & $D$ & $\mathbf{N}$ & A \\
\hline 14. I enjoy playing math games. & SD & $D$ & $\mathbf{N}$ & $A$ \\
\hline 15. I can tell if my answers in math make sense. & SD & $D$ & $\mathbf{N}$ & A \\
\hline 16. I enjoy studying math. & SD & $D$ & $\mathbf{N}$ & $A$ \\
\hline 17. Doing math is easy for me. & SD & $D$ & $\mathbf{N}$ & A \\
\hline 18. Solving math problems is fun. & SD & $D$ & $\mathbf{N}$ & $\boldsymbol{A}$ \\
\hline
\end{tabular}

\section{About you:}

- Are you a boy or girl?

- Please circle which grade you are in: $\quad 3^{\text {rd }} 4^{\text {th }} 5^{\text {th }} 6^{\text {th }}$

- Please circle your ethnicity (you may circle more than one)

Asian or Pacific Islander

Black

Hispanic

Native American or Alaska Native

White 


\section{APPENDIX B}

\section{Math and Me Survey: Teacher Questionnaire}

\section{Your gender:}

Please circle your ethnicity (you may circle more

than one):

Asian or Pacific Islander

Black

Hispanic

Native American or Alaska Native

White

\section{How many years have you been teaching?}

Please circle which degrees you have (you may circle more than one): B.A. / B.S. Rank I
M.Ed. / M.A.
Rank II Ph.D.Ed.D.

Is this class a self-contained gifted and talented class?

Using the student ID numbers on the cover pages you were given, please complete the table with the following information:

Enjoyment - Rate the student's level of enjoyment of mathematics. Enjoyment is the degree to which the student takes pleasure in learning and doing mathematics.

$1=$ Very low level of enjoyment of mathematics

2 = Low level of enjoyment of mathematics

$3=$ Moderate level of enjoyment of mathematics

$4=$ High level of enjoyment of mathematics

$5=$ Very high level of enjoyment of mathematics

Self-Perceptions - Rate the student's level of mathematical self-perceptions. Selfperceptions are the student's perceptions of self as a mathematical learner, including beliefs about his/her ability to learn and perform well in mathematics.

$1=$ Very low level of mathematical self-perceptions

$2=$ Low level of mathematical self-perceptions

$3=$ Moderate level of mathematical self-perceptions

$4=$ High level of mathematical self-perceptions

$5=$ Very high level of mathematical self-perceptions 
Student Math/Reading Ability - Rate the student's ability in math and in reading (separately).

$1=2$ or more grades below grade level

$2=$ About 1 grade below grade level

$3=$ Grade level

$4=$ About 1 grade above grade level

$5=2$ or more grades above grade level 


\begin{tabular}{|c|c|c|c|c|}
\hline $\begin{array}{c}\text { Student } \\
\text { ID \# }\end{array}$ & $\begin{array}{c}\text { Enjoyment } \\
\quad(1-5)\end{array}$ & $\begin{array}{c}\text { Self- } \\
\text { Perceptions } \\
(\mathbf{1 - 5})\end{array}$ & $\begin{array}{c}\text { Student } \\
\text { Math } \\
\text { Ability } \\
\text { (1-5) }\end{array}$ & $\begin{array}{c}\text { Student } \\
\text { Reading } \\
\text { Ability } \\
\text { (1-5) }\end{array}$ \\
\hline \multicolumn{5}{|l|}{111} \\
\hline \multicolumn{5}{|l|}{112} \\
\hline \multicolumn{5}{|l|}{113} \\
\hline \multicolumn{5}{|l|}{114} \\
\hline \multicolumn{5}{|l|}{115} \\
\hline \multicolumn{5}{|l|}{116} \\
\hline \multicolumn{5}{|l|}{117} \\
\hline \multicolumn{5}{|l|}{118} \\
\hline \multicolumn{5}{|l|}{119} \\
\hline \multicolumn{5}{|l|}{120} \\
\hline \multicolumn{5}{|l|}{121} \\
\hline \multicolumn{5}{|l|}{122} \\
\hline \multicolumn{5}{|l|}{123} \\
\hline \multicolumn{5}{|l|}{124} \\
\hline \multicolumn{5}{|l|}{125} \\
\hline \multicolumn{5}{|l|}{126} \\
\hline \multicolumn{5}{|l|}{127} \\
\hline \multicolumn{5}{|l|}{128} \\
\hline \multicolumn{5}{|l|}{129} \\
\hline \multicolumn{5}{|l|}{130} \\
\hline \multicolumn{5}{|l|}{131} \\
\hline \multicolumn{5}{|l|}{132} \\
\hline \multicolumn{5}{|l|}{133} \\
\hline \multicolumn{5}{|l|}{134} \\
\hline \multicolumn{5}{|l|}{135} \\
\hline \multicolumn{5}{|l|}{136} \\
\hline 137 & & & & \\
\hline
\end{tabular}




\title{
CURRICULUM VITAE
}

\author{
Dericka D. Canada \\ College of Educational and Counseling Psychology \\ 362 College of Education \\ University of Louisville \\ Louisville, Ky 40292 \\ Phone: (859) 229-0376 \\ dericka.canada@louisville.edu
}

\section{Education}

Diploma, Paul Laurence Dunbar High School, Lexington, KY. May, 2005.

B.A. Psychology, with Concentration in Social Sciences, University of Louisville, Louisville, KY. Summa Cum Laude

Honor's Thesis: Cross-Cultural Comparison of Social Anxiety Symptoms Among European American and African American College Students.

May, 2009.

M.Ed. Counseling Psychology, University of Louisville, Louisville, KY. Master's Thesis: Turning the Key to Success: An Examination of the Mathematical Attitudes of African American Elementary Students (in progress).

Expected Graduation: August 2011.

Ph.d. Counseling Psychology, Boston College, Boston, MA.

Enrolling Fall 2011

Expected Graduation: May 2016

\section{Academic Experience}

Undergraduate Courses: Intro to Psychology, Personality, Social Problems, Drugs and Behavior, Multi-cultural Psychology, Lifespan Developmental Psychology, Cognitive Processes, Abnormal Psychology, Research Psychology-Intern, Social Statistics, Experimental Psychology, Research Practicum in Psychology, Racial Differences of Social Anxiety Symptoms-Honors Research.

Graduate Courses: Social, Legal, and Ethical Issues in Counseling, Empirical and Theoretical Foundations of Counseling Psychology, Evaluation and Measurement, 
Career Counseling, Applied Statistics, Differential Diagnosis, Theories and Techniques of Counseling, Psychological Assessment-Intelligence, Life Span and Human Development, Multi-cultural Counseling, Psychological Assessment-Personality, Supervised Research, Intermediate Statistics, Learning and Cognition, Biological Bases of Behavior. .

\section{Professional Experience}

Graduate Teaching Assistant, Educational and Counseling Psychology Program, College of Education and Human Development, University of Louisville, Louisville, KY, Spring 2010 to present.

Graduate Research Assistant, Educational and Counseling Psychology Program, College of Education and Human Development, University of Louisville, Louisville, KY, August 2009 to present.

Undergraduate Student Research Assistant, Cooperative for African American Family Excellence (CAFÉ) Research Lab, August 2008 to May 2009.

Undergraduate Peer Mentor, Caring of New Students Experiencing College Transition (C.O.N.E.C.T.) Peer Mentoring Program, College of Arts and Sciences Advising Center, University of Louisville, Louisville, KY, 2006 to 2008.

Undergraduate Mentor, Undergraduate Students Helping to Recruit (U.S.H.R.), University of Louisville Office of Admissions, Louisville, KY, 2005 to 2008.

\section{Clinical Experience}

Graduate Intern, Counseling Psychology Intern at Seven Counties Services, Specialized Child and Family Services, Louisville, Ky

January 2011-Present

Graduate Intern, Counseling Psychology Practicum at Archdiocese of Louisville Parish Counseling Services/St. Bernard School, Louisville, KY

August 2010-December 2010

Psychology Intern, Louisville Central Community Center, Louisville, KY Spring 2008

Student Intern through Experienced Based Career Education (EBCE), Florence Crittenton Home for Pregnant Teens, Lexington, KY Spring 2005

Student Intern, Guidance Counseling Office through EBCE, Tatescreek Elementary,

Lexington, KY Fall 2004

Student Intern, Guidance Counseling Office through EBCE, Cardinal Valley Elementary, Lexington, KY

Fall 2004 


\section{Research Projects}

\section{Graduate Research}

Evaluation of Girls on the Run Program Louisville, KY, Research Assistant, University of Louisville, Supervised by Dr. Jill Adelson, Department of Educational and Counseling Psychology.

Examination of the Mathematical Attitudes of African American Elementary Students, Master's Thesis, University of Louisville.

Reactions to Racial/Ethnic Dyads within an Academic Setting, Research Assistant, University of Louisville, Supervised by Dr. Jesse Owen, Department of Educational and Counseling Psychology.

Mathematics Attitudes of Elementary School Children Grades 3 through 6, Research Assistant, University of Louisville, Supervised by Dr. Jill Adelson, Department of Educational and Counseling Psychology.

Acculturation and Well Being among Asian-Americans, Research Assistant, University of Louisville and University of California, Los Angelas, Supervised by Dr. Jeff Valentine, Department of Educational and Counseling Psychology at University of Louisville; and Dr. Arparna Gupta, Semel Institute for Neuroscience and Human Behavior at UCLA.

Predicting Student Outcomes from Information Knowable at the Time of Hire, Research Assistant, University of Louisville, Supervised by Dr. Jeff Valentine, Department of Educational and Counseling Psychology.

Examination of Biased Outcome Reporting in Educational Research, Research Assistant, University of Louisville and Loyola University Chicago, Supervised by Dr. Jeff Valentine, Department of Educational and Counseling Psychology at University of Louisville; and Dr. Terri Pigott, Department of Education at Loyola University Chicago.

Effects of Gravity and Sleep Deprivation on Brain Functioning, Data Management, National Aeronautics and Space Administration (NASA) and University of Louisville, Supervised by Dr. Jill Adelson, Department of Educational and Counseling Psychology.

\section{Undergraduate Research}

Cross-Cultural Comparisons of Social Anxiety Symptoms among European American and African American College students, Senior Honors Research Project, University of Louisville, Supervised by Dr. Kevin Chapman, Department of Psychological and Brain Science. 
Anxiety, "Nerves", and Stress in African American Families, CAFÉ Lab Research Assistant, University of Louisville, Supervised by Dr. Kevin Chapman Department of Psychological and Brain Sciences.

A Cross-Cultural Comparison of Worry Symptoms among European American and African American Young Adults, Research Assistant, Supervised by Dr. Kevin Chapman, Department of Psychological and Brain Sciences.

\section{Honors and Awards}

\section{Fellowships, Grants, and Scholarships}

University Fellow, Department of Graduate Studies, University of Louisville, 2009 to present.

Undergraduate Scholarship, Society of Woodford R. Porter Scholars, 2005 to 2009. Scholarship Recipient, Toyota Manufacturing Kentucky, 2005 to 2009.

Scholarship Grant Recipient, Alpha Kappa Alpha Sorority, Inc. Highest Regional GPA Award- South African Tour, 2008.

\section{Awards}

Graduation Summa Cum Laude, Bachelor of Arts in Psychology, University of Louisville, May 2009.

Undergraduate Student Award and Induction, University of Louisville Woodcock Honor Society 2009.

Undergraduate Student Award and Membership, National Society of Collegiate Scholars, 2005 to 2009.

Undergraduate Student Award and Membership, Psychology Honors Program, Psychological and Brain Sciences, University of Louisville, 2008 to 2009.

Dean's Scholar (4.0)-Undergraduate, University of Louisville: Spring 2007; Spring 2008; Spring 2009.

Dean's List (Above 3.5)-Undergraduate, University of Louisville: Fall 2005, Spring 2006; Fall 2006, Fall 2007; Fall 2008.

Award Recipient, University of Louisville Yarmuth Book Award, 2005.

Award Recipient and Membership, National Scholars of High School Students, 2002 to 2005.

Award Recipient and Membership, Who's Who Among High School Students, 2002 to 2005.

Award Recipient and Membership, Youth Salute, 2004 to 2005.

\section{University Courses Taught}

University of Louisville. Psychological Evaluation and Measurement, Graduate Course (TA). 


\section{Publications}

\section{Peer Reviewed Articles}

Valentine, J. C., Rakes, C. R., \& Canada, D. (2010). Predicting student outcomes from information knowable at the time of hire: A systematic review. Report submitted to the U.S. Department of Education, grant award \# U215K050530.

\section{Journal Articles in Preparation or Review}

Canada, D. D. \& Adelson, J. L. (in preparation). Turning the Key to Success: An Examination of the Mathematical Attitudes of African American Elementary Students.

Gupta, A., Leong, F., Valentine, J. C., \& Canada, D. (in preparation). Acculturation and Well-Being among Asian Americans: A Meta-Analytic Study.

Pigott, T. D., Valentine, J. C., Williams, R. T., \& Canada, D. (in preparation). Examination of Biased Outcome Reporting in Educational Research.

\section{Conference Presentations}

Canada, D. D. \& Adelson, J. A. (2011). Turning the Key to Success: An Examination of the Mathematical Attitudes of African American Elementary Students. Will present at the American Psychological Association 2011 Conference, Washington, DC.

Pigott, T. D., Valentine, J. C., Williams, R. T., \& Canada, D. (2010). Examination of Biased Outcome Reporting in Educational Research. Presented at the 2010 conference of the Society for Research on Educational Effectiveness, Washington DC.

Canada, D. D., Alexander, K. M., \& Chapman, L. K. (2009). Cross cultural comparison of social anxiety symptoms among European American and African American college students across matched-income. Kentucky Psychological Association Spring Convention, Lexington, KY.

Alexander, K. M., Canada, D. D., \& Chapman, L. K. (2009). A cross cultural comparison of worry symptoms among European American and African American young adults. Kentucky Psychological Association Spring Convention, Lexington, KY.

\section{Professional Affiliations}

American Psychological Association (APA) 2010-Present American Psychological Association for Graduate Students (APAGS)

Kentucky Psychological Association (KPA) 2007-2009

Association of Behavioral and Cognitive Therapist (ABCT) 2008-2009

National Society of Collegiate Scholars (NSCS) 2005-2009 